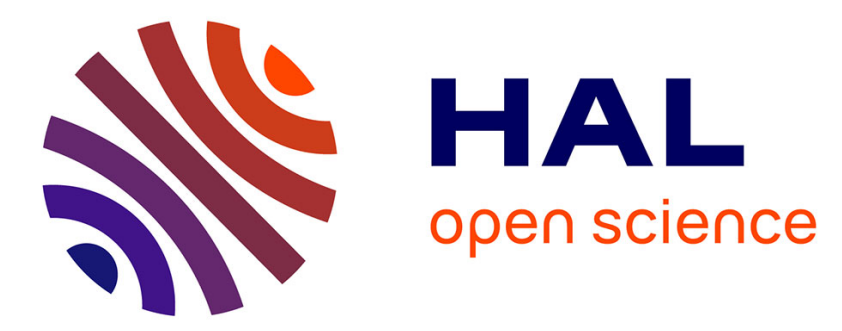

\title{
Systematical position and paleoecology of the endemic deer Megaceroides algericus Lydekker, 1890 (Cervidae, Mammalia) from the late Pleistocene-early Holocene of North Africa \\ Roman Croitor
}

\section{To cite this version:}

Roman Croitor. Systematical position and paleoecology of the endemic deer Megaceroides algericus Lydekker, 1890 (Cervidae, Mammalia) from the late Pleistocene-early Holocene of North Africa. Geobios, 2016, 49 (4), pp.265-283. 10.1016/j.geobios.2016.05.002 . hal-01766151

\section{HAL Id: hal-01766151 \\ https://hal.science/hal-01766151}

Submitted on 18 Apr 2018

HAL is a multi-disciplinary open access archive for the deposit and dissemination of scientific research documents, whether they are published or not. The documents may come from teaching and research institutions in France or abroad, or from public or private research centers.
L'archive ouverte pluridisciplinaire HAL, est destinée au dépôt et à la diffusion de documents scientifiques de niveau recherche, publiés ou non, émanant des établissements d'enseignement et de recherche français ou étrangers, des laboratoires publics ou privés. 


\title{
Systematical position and paleoecology of the endemic deer Megaceroides algericus Lydekker, 1890 (Cervidae, Mammalia) from Late Pleistocene - Early Holocene of North Africa
}

\author{
Roman CROITOR \\ Aix-Marseille University, CNRS, UMR 7269, MMSH BP674, rue du Château de I'Horloge 5, F-13094 Aix-en-Provence, France; \\ Institute of Zoology, Academy of Sciences of Moldova, Academiei str. 1, MD-2028, Chișinău, Moldova; romancroitor@europe.com
}

\begin{abstract}
The unusual cranial morphology of the endemic extinct African deer Megaceroides algericus (Lydekker, 1890) is described in the present article. Some details of cranial and dental morphology suggest that Megaceroides algericus is closely related to the Eurasian giant deer Megaloceros giganteus (Blumenbach, 1799). The paper presents also a discussion on paleoecology and functional morphology of Megaceroides algericus, its origin, phylogenetic and taxonomic position. Megaloceros mugarensis (di Stefano, 1996) from Middle Pleistocene of Levant is regarded as a probable forerunner of Megaceroides algericus.
\end{abstract}

Keywords: Cranial morphology, Pachyostosis, Evolution, Ecomorphology, Taxonomy, Paleobiogeography.

\section{Introduction}

Cervidae represents a successful family of ruminants that arose in the mid-Tertiary period in Eurasian tropics, however, because of its specific evolutionary and ecological strategy, this rich in species and ecological forms family, apart from a few exceptions, failed to colonize the African continent. According to Geist (1998), cervids with their low forage habit specialization are poor food competitors with other groups of herbivores, like bovids and equids, in old species-rich ecosystems among coevolved ecological specialists. Ecologically opportunistic cervids are most successful in young ecosystems with large amplitude of environmental fluctuations (Geist, 1998). The paleontological record and modern fauna give only two examples of successful evolutionary survival of cervids on the African continent: Megaceroides algericus (Lydekker, 1890) and Cervus elaphus barbarus Bennet, 1833 (Gentry, 2010).

The origin and systematical position of the mysterious North African fossil deer Megaceroides algericus is a subject to debates and contradictions in the scientific literature for more than a century. The extinct species $M$. algericus represents the exceptional zoogeographic instance of an endemic extremely specialized form of deer that evolved on the African continent. The second African cervid, Cervus elaphus barbarus, is a primitive small-sized subspecies of red deer, which survived until the present days and does not show unusual or particular evolutionary specializations, possibly with exception of some traits of paedomorphosis (Geist, 1998). The isolated and very restricted North African distribution of M. algericus represents a very interesting, but still poorly understood evolutionary and paleozoogeographic case. The present article propose a taxonomic, morphological, morpho-functional, paleobiological, and phylogenetic study of the "thick-jawed deer" M. algericus that aims to contribute to the better understanding of this rare zoogeographic instance of endemic North African cervid.

\section{Historical background}

The first description of the species belongs to Lydekker (1890). He described a maxilla with an upper tooth series comprising $\mathrm{P}^{4}-\mathrm{M}^{3}$ of a medium-sized deer from Hammam Mescoutine (Algeria) as Cervus algericus, noting a strongly developed cingulum, and assumed a possible phylogenetic relationship of the new 
species with the giant deer Megaloceros giganteus. Some-what later, Pomel (1892) created another species Cervus pachygenys, which was based on a very pachyostotic and quite bizzare ("pathological", according to Pomel, 1893) lower mandibles from Neolithic of Algeria. The sample described by Pomel (1893) also included an isolated upper molar without lingual cingulum. Joleaud $(1914,1916)$ brought together in synonymy Lydekker's and Pomel's species and stressed the affinity between the African deer and the European giant deer, assuming for the African form an intermediate position between Megaloceros and Dama. Joleaud $(1914,1916)$ placed the North African deer in his new subgenus Megaceroides within the genus Cervus in order to underline its assumed archaic character and transitional systematic position. Arambourg $(1932,1938)$ elevated Megaceroides to the genus level and reported on some new important findings of cranial remains of Megaceroides algericus from Algeria (Guyotville) and Morocco (Ain Tit Mellil). Arambourg (1938) provided figures of those findings, but did not describe them in details.

The studies of Italian researchers published in the second half of the XX-th century gave a new impetus to the debates on taxonomy and systematical position of the endemic African cervid. Azzaroli (1953) proposed a new evolutionary and systematic model of the genus Megaloceros, which included all giant and some smaller plesiometacarpal Old World cervids, including presumed descended Late Pleistocene dwarfed forms from Mediterranean islands and Megaceroides algericus. Azzaroli (1953) divided the genus Megaloceros Brookes, 1828 (the genus name Megaceros Owen, 1843 was applied in the cited work) into two informal evolutionary branches called the "giganteus group" and the "verticornis group" after the best known species representing each stock. Megaceroides algericus, according to Azzaroli (1953), is a terminal form of the "verticornis group" with signs of evolutionary "degeneration", such as a small body size, the extreme degree of hyperostosis, and a very marked shortening of the muzzle. Azzaroli (1953: page 48) recognized that the relationship of $M$. algericus with European forms is not clear, therefore he avoided using the name Megaceroides in his evolutionary model of giant deer. Nonetheless, Azzaroli (1953) indicated some morphological characters of Megaceroides algericus, such as the flattened shape of the frontlet and traits of "stunting" in the antler morphology and overall size, which permitted to Azzaroli to include the North African cervid in his "verticornis group". Azzaroli (1953) noticed that M. algericus coincides in some features with Sinomegaceros pachyosteus (placed by Azzaroli, 1953 in the "giganteus group") in its smaller body size, the extreme degree of hyperostosis, and the shortening of the muzzle. Ambrossetti (1967) accepted Azzaroli's opinion and placed all "verticornis-like" deer from Europe together with Algerian endemic deer in the subgenus Megaceros (Megaceroides). Later, Azzaroli and Mazza (1993) elevated Megaceroides to the generic rank. Azzaroli's (1953) suggestion on the morphological affinity between Megaloceros algericus and Sinomegaceros pachyosteus was supported later by Thomas (1979) and Hadjouis (1990).

Finally, Azzaroli $(1979,1994)$ assumed that Megaceroides algericus and Praemegaceros dawkinsi (=Megaceroides dawkinsi according to Azzaroli, 1979) resulted from a similar evolutionary processes of dwarfing caused by geographical isolation in unfavorable conditions. The flat shape of the frontal bones, the similarly diminished body size, and the disproportionately thin antler beams with respect to relatively large antler burrs and robust pedicles are regarded as stunting traits shared by $M$. algericus and $P$. dawkinsi (Azzaroli and Mazza, 1993).

Kahlke (1965) proposed the old genus name Praemegaceros Portis, 1920 (substituting the genus name Orthogonoceros Kahlke, 1956 with type species Cervus verticornis Dawkins, 1872) for European deer of the "verticornis group", thus disregarding Azzaroli's (1979) suggestion of a close phylogenetic relationship 
between Megaceroides algericus and the "verticornis group". Somewhat later, Radulesco and Samson (1967) published a detailed taxonomical study of Pleistocene large-sized deer and confirmed the validity of the genus name Praemegaceros for the "verticornis group", acting as first revisers. The endemic British deer Cervus dawkinsi Newton, 1882 was designated as a type species of the genus Praemegaceros (Radulesco and Samson, 1967). From that point, debates on the taxonomy of large-sized deer from Pleistocene of Western Palearctic became very confusing, since the disputed genera Praemegaceros and Megaceroides were typified by poorly known endemic and morphologically odd species Praemegaceros dawkinsi and Megaceroides algericus. Vislobokova (2012a: page 687, 2012b: page 58; 2013: page 911) regards Cervus verticornis Dawkins, 1872 as the type species of Praemegaceros and granted to Kahlke (1965) the title of first reviewer of the genus. Nonetheless, Vislobokova (2012b: page 61; 2013: page 913) in also proposes Cervus dawkinsi as a type species of the nominotypical subgenus Praemegaceros (Praemegaceros). It is necessary to keep in mind that Praemegaceros Portis, 1920 was originally based on Cervus dawkinsi, while Cervus verticornis together with Cervus savini Dawkins, 1887 and Cervus falconeri Dawkins, 1868 were included in Praedama Portis, 1920 (Portis, 1920; Radulesco and Samson, 1967; Azzaroli, 1979) and, therefore, can not be used as type species for Praemegaceros. According to the Article 44 of ICZN, a genus and its nominotypical subgenus are denoted by the same type species.

Hadjouis (1990) regarded Megaceroides as a subgenus of Megaceros Owen and proposed an improved neodiagnosis for Megaceroides and a synonymy list of $M$. algericus. In opinion of Hadjouis (1990), the morphology of the dentition (first of all, the strongly developed cingulum on upper molars) and the extremely strong mandibular pachyostosis approach $M$. algericus to the Asian large-sized deer Sinomegaceros pachyosteus, thus one more time supporting the Azzaroli's (1953) previous observation. The missing posterior tine in antlers of $M$. algericus was regarded by Hadjouis as one of the most important characters distinguishing the African endemic deer from European giant deer. Nonetheless, the viewpoint of Hadjouis has been contested by Azzaroli and Mazza (1993) and Azzaroli (1994), who put in question the taxonomical value of the cingulum in upper molars and the mandibular pachyostosis, which, according to the Italian authors, are quite variable in large-sized deer.

Abbazzi (2004) pointed out the resemblance of neurocranium shape of Megaceroides algericus with Praemegaceros solilhacus (Robert, 1829) and P. dawkinsi, however, she did not discuss the phylogenetic position of M. algericus and, following the opinion of Hadjouis (1990), restricted Megaceroides to the type species. Gentry (2010) included Megaceroides in the synonymy of Megaloceros.

Vislobokova (2009, 2012a, 2012b, 2013) included Megaceroides in the tribe Megacerini Viret, 1961 that contains a large number of continental and insular Late Miocene - Pleistocene cervids presumably closely related to the genera Megaloceros and Praemegaceros. Vislobokova (2012b, 2013) suggests that Megaceroides is a monotypic taxon that includes a single peculiar cervid form closely related to European Praemegaceros and possibly may be included in the latter genus as a subgenus in the case if its belonging to Praemegaceros will be demonstrated. Vislobokova (2012b, 2013) also regards Azzaroli's informal verticornis-group and giganteus-group as subtribes Praemegacerina and Megacerina within the tribe Megacerini. Since the phylogenetic relationships among the so-called "giant deer" (including also some smaller continental forms and insular dwarfs) are not well founded (Croitor, 2006), the new taxonomical units proposed by Vislobokova most probably are polyphyletic.

The taxonomical revision of the genus Praemegaceros and a preliminary account on systematical position, morphology, and paleoecology of Megaceroides algericus were published in our previous reports (Croitor, 
2004, 2006, 2014; Croitor and Bonifay, 2001; Croitor and Kostopoulos, 2004; Croitor and al., 2006). We pointed out that the morphology of the dentition (the presence of the cingulum in upper molars, the relatively short lower premolar series, and the brachyodonty) approach the Algerian deer to Megaloceros giganteus from moderate latitudes of Central and Western Eurasia (Croitor and Bonifay, 2001). Therefore, we adjoined the opinion of Radulesco and Samson (1967) on the validity of the genus name Praemegaceros for the "verticornis group". Later, a direct phyletic relationship between dwarfed Middle Pleistocene Praemegaceros dawkinsi and larger Early Pleistocene Praemegaceros obscurus was suggested (Croitor, 2006). This point of view is supported, inter alia, by the presence of vestigial basal antler tines in P. dawkinsi, which are homologous with long and strong basal tines in P. obscurus.

Regarding the size and proportions of the braincase from Ain Tit Mellil discovered by Arambourg (1938) and the pachyostotic mandibles from various North African sites, I pointed out the disproportion between the relatively broad and large braincase and the short and weak anterior part of the mandibles, presuming the mixed character of the material ascribed to Megaceroides algericus and, therefore, I proposed to exclude the African material from the taxonomical debates of European large-sized cervid forms (Croitor, 2004). Later, I had the opportunity to study the complete skull of Megaceroides algericus from Guyotville (figured by Arambourg, 1932) that represents a poorly understood and aberrant morphological specialization for Cervidae (Croitor, 2006). In my previous publication, only a general description and some measurements of the cranial and mandibular material of $M$. algericus were published, however, even that brief overview provides arguments against its use as a type species for giant and dwarfed deer arbitrarily placed in the "verticornis group" and now included in the genus Praemegaceros (Croitor, 2006, 2014).

Despite of the available fine cranial and dental material, antlers and postcranial bones of Megaceroides algericus are little known. Pomel (1893) described and figured a damaged, but obviously very robust and relatively short cervid radius from Berrouaghia (Algeria) characterized by a comparatively broad bone shaft (the mid-shaft measurement amounts to $40 \mathrm{~mm}$, exceeding the analogous measurements of Megaloceros giganteus) and two fragments of slightly compressed from the sides (latero-medially) antler tines. Hadjouis (1990) described several shed antlers of Megaceroides algericus from Phacocheres (Algeria) with the missing distal part of palmation and the anterior (middle) tine, as well as a fragment of a narrow distal palmation. These specific although very incomplete data on the antler and postcranial morphology of Megaceroides algericus suggest peculiar eco-morphological adaptations, but practically do not contribute to the understanding of paleoecology and evolution of this species.

Nonetheless, despite of long lasting debates on its systematical position and phylogenetic relationships, even the fine available cranial material of Megaceroides algericus is still rather superficially described. In the present paper, a detailed morphological description of the cranial remains and dentition of Megaceroides algericus and a discussion on its paleoecology and phylogenetic relationships are provided.

\section{Material and methods}

The described fossil material comes from the old historical collections stored in the National Museum of Natural History in Paris. All fossil remains are yielded by archaeological Paleolithic sites, however, their exact stratigraphic provenance and absolute age remain unclear. Nonetheless, the detailed morphological description of the material included in the study was never published before and represent a significant information gap that impede the advance of our knowledge of taxonomy, systematics and phylogeny of 


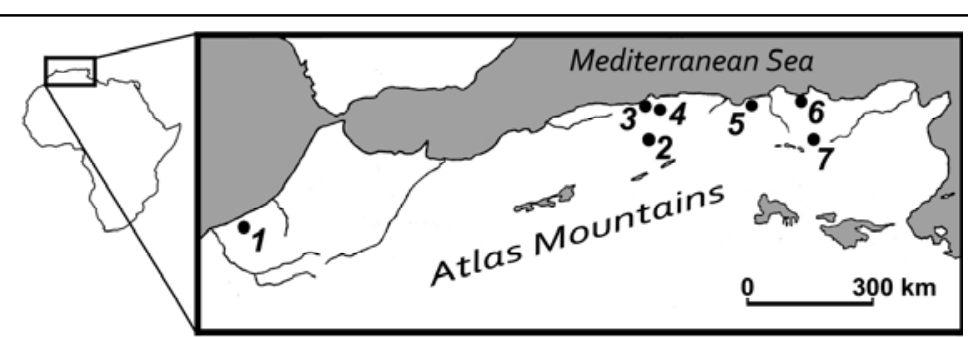

Figure 1. Fossiliferous sites considered in the present study: 1, Ain Tit Mellil (Morocco); 2, Berrouaghia (Algeria), the type locality of Cervus pachygenys Pomel, 1892; 3, Guyotville (Algeria); 4, Phacocheres (Algeria); 5, Grotte de la Madeleine (Algeria); 6, Filfila (Algeria); 7, Hammam Meskoutin (Algeria), the type locality of Cervus algericus Lydekker, 1890.
Eurasian large sized and endemic Mediterranean deer. The studied material (Tab. 1) comes from the following sites (Fig. 1):

Guyotville (= Ain-Benian: Hadjouis, 1990; = Anglade: Fernandez et al., 2015 ; = Sintès: Camps, 1992), Algeria. The associated with Mousterian industry local fauna from Guyotville was characterized by Arambourg (1935) as a Middle Paleolithic assemblage due to the

presence of Rhinoceros mercki and Hippopotamus amphibius. The better preserved antlered skull (distal portions of antlers are not preserved, no collection number) from Guyotville was excavated and briefly described by Arambourg (Arambourg, 1932: fig. 3) and has been mentioned by Azzaroli and Mazza (1993) with regard to its forehead shape. Hadjouis (1990) quotes briefly some cranial characters based on the specimen from Guyotville and published measurements of its dentition. Only an approximate condylobasal length of this skull could be measured (Croitor, 2006), since its occipital condyles and foramen magnum were destroyed, apparently, by ancient hunters who extracted the brain tissue from the braincase. The sample from Guyotville includes also two hemimandibles (Nr. 336, Nr. 337, "Collection of Arambourg"), which remained unpublished.

Ain Tit Mellil (= Tit Mellil: Vaufrey, 1955), Morocco. The exact stratigraphic origin of the fossil remains is unknown and they age was generally assumed as "the beginning of Würm glaciation" (Vaufrey, 1955). The braincase MOC148 from Ain Tit Mellil (figured in Arambourg, 1938: pl. II, fig. 2) was briefly discussed by Abbazzi (2004: fig. 6) and Vislobokova (2013: fig. 56, a, b).

Grotte de la Madeleine (= Taza 1: Fernandez et al., 2015), Algeria. The Paleolithic site Taza 1 includes three layers dated from >39 000 to $13800 \pm 130$ y. BP (uncalibrated: Medig et al., 2005). Therefore, Late Pleistocene age is assumed for historical collection of fossils yielded by this site (Fernandez et al., 2015). The studied material includes two fragmented mandibles: the well preserved right hemimandible figured in Croitor (2006: fig. 2 A-B; no collection number) and another specimen with a malformation in the area of processus angularis (no collection number). The museum label provides the following information: "Cervus algericus - figuré: PI. IV, Fig. 4", however, this label does not contain any bibliographic information.

Filfila, Algeria. A Würmian age was assumed for the fauna from Filfila (Ginsburg et al., 1968). The sample of Megaceroides algericus from Filfila, Algeria (Thomas, 1979) includes a fragment of right upper jaw FIL169 with $\mathrm{M}^{2}$ and $\mathrm{M}^{3}$ and three hemimandibles (FIL166, FIL167, and juvenile FIL160). Only the better preserved specimen FIL166 was figured by Thomas (1979) and Abbazzi (2004: fig. 7).

The specific character of fossil material (fragmentary skeletal remains, limited number of fossils) restricted the choice of methodological approach. The safest estimation of cranial and dental morphological characters of Megaceroides was possible with involving of few "typical" evolutionary and ecological cervid forms, like Dama dama (apparently, one of the closest to Megaceroides species, which maintains generalized cervid cranial morphology), Megaloceros giganteus (a giant species characterized by pachyostosis as Megaceroides algericus), Muntiacus muntjak (a tropical forest dweller, which possibly 
maintain the basic for Cervinae cranial morphology and proportions), and Hydropotes inermis (belongs to the subfamily Capreolinae, but represents a rare for cervids example of ecological specialization connected to the periaquatic ecological niche). The comparative craniological material includes a series of skulls and mandibles of the modern fallow deer Dama dama, Muntiacus muntjak, and Hydropotes inermis stored in the osteological collection of the Zoological Museum "La Specola" (ZMS, Florence, Italy) and in the Natural History Museum of London (NHML), red deer Cervus elaphus stored in the zoological collection of the National Museum of Natural History in Paris (NMNH), and Megaloceros giganteus from various Late Pleistocene sites of Ireland (NHML). The main measurements of the comparative material are presented in the tables 2 and 3 . The statistical processing of data was not possible because of the restricted number of fossil material, but also because of quality and mixed character of the comparative osteological material, which I had at my disposal: the cranial material of some species ( $M$. muntjak and $H$. inermis) was not numerous, besides that, many specimens were obtained from parks, zoological gardens, and did not represent natural populations, therefore, the statistical processing of data became senseless. Therefore, a single male skull of each species was selected for the comparative study.

The lengths of dental series are taken at the crown bases or at alveoli. The length of tooth crown is taken as a maximal measurable value. The length of tooth crown in upper cheek teeth is measured at the labial side of grinding surface. The breadth of tooth crown is measured at crown base. The terminology of dental morphology is adapted from Heintz (1971). The applied methodology of cranial measurements is adapted from Vislobokova (1990). The applied terminology of antler tines follows the homology of tines according to Azzaroli and Mazza (1993) and Croitor (2006).The body mass estimation used here is based on dental variables according to Janis (1990). Abbreviations used in the text: PP, premolar series; MM, molar series; $L$, length; $H$, height; $D$, width/breadth.

\section{Systematic paleontology}

Family Cervidae Goldfuss, 1820

Subfamily Cervinae Goldfuss, 1820

Genus Megaceroides Joleaud, 1914

\section{Megaceroides algericus (Lydekker, 1890)}

1890. Cervus algericus sp. nov. - Lydekker, p. 602, fig. 1.

1892. Cervus pachygenys sp. nov. - Pomel, p. 213.

1893. Cervus pachygenys (Pomel) - Pomel, p. 35, pl. VII, figs. 1-7, pl. VIII, figs. 1-4.

1914. Cervus (Megaceroides) algericus Lydekker - Joleaud, p. 737.

1938. Megaceroides algericus (Lydekker) - Arambourg, p. 33, fig. 8.

1953. Megaceros algericus (Lydekker) - Azzaroli, p. 47, p. 51.

1967. Megaceros (Megaceroides) algericus (Lydekker) - Ambrosetti, p. 272.

1990. Megaceros (Megaceroides) algericus (Lydekker) - Hadjiouis, p. 249, figs. 1-4.

2010. Megaloceros algericus (Lydekker) - Gentry, p. 813. 
Holotype: the left maxilla with $\mathrm{P}^{3}-\mathrm{M}^{3}$ (Lydekker, 1890; figured on page 602), $\mathrm{P}^{2}$ is completely destroyed, while $\mathrm{M}^{2}$ and $\mathrm{M}^{3}$ are damaged; the cast is stored at the Natural History Museum of London (Lydekker, 1890: p. 604), collection number $M 10647$ (Gentry, 2010). The length of upper molar series $M^{1}-M^{3}$ amounts to $58.5 \mathrm{~mm}$ (measured from the figure). The location of the original fossil specimen is unknown. The holotype is characterized by the strong development of a basal enamel cingulum in the upper molars.

Type locality and horizon: Late Pleistocene from Hammam Meskoutin, Guelma (Algeria).

Occurrence: Late Pleistocene - Holocene (ca. 24,000 to 6641-6009 yr. BP; Fernandez et al., 2015).

Original diagnosis (Lydekker, 1890: page 603): Somewhat smaller than Cervus cashmirianus, with brachyodont molars, having a very large inner cingulum, and the external surface complicated by the excessive development and reflection of the lateral ridges of the outer crescents so as to form distinct pockets on this surface at the base of the ridges in question.

Emended diagnosis (this work): A cervid species of medium size, slightly larger than modern fallow deer and smaller than red deer. The skull is very broad: the skull breadth attains more than $60 \%$ of the condylobasal length. Splanchnocranium is relatively short: the length measured from the anterior edge of the orbits to the prosthion makes is shorter than $1 / 2$ of the condylobasal length. Skull bones with exception of zygomatic arches are very thick. Braincase is moderately flexed: the angle between parietal bones and face profile amounts to ca. $135^{\circ}$; parietal bones are flat. Pedicles are moderately long (their length approximately equals to their transversal diameter), deflected sideward and some-what backward. Frontal bones are flat and very broad. Orbits are comparatively large; their anterior edges lay at the level between $\mathrm{M}^{2}$ and $\mathrm{M}^{1}$. Ethmoidal vacuities are completely closed. Preorbital fossae are not developed. Basioccipitale is broad and bell-shaped. Upper canines are missing. The cingulum in upper molars is variable: it may be well-developed, or almost completely missing. Lower fourth premolar $\left(\mathrm{P}_{4}\right)$ is molarized: its metaconid is fused with paraconid. Mandible is very pachyostosic, with low anterior part. The transversal section of the anterior portion of the hemimandible is circular. Antlers terminate with a palmation. The proximal part of antler beam has a circular transversal section and lacks basal tines. The tine inserted on the anterior side of the beam (homologous with the middle tine in Megaloceros giganteus) is situated from the burr at a distance ca. two times exceeding the diameter of antler base.

\section{Description:}

SKULL: The cranium from Guyotville belongs to a rather aged individual with completely obliterated sutures and deeply worn upper dentition (Figs. 2, 3). The area of left eye socket is damaged. The basioccipital part and anterior part of premaxillary bones are destroyed, so the condylobasal length and some other measurements of the skull are given with approximation (Tab. 4). The overall shape of cranium is atypical. The relatively short and very broad skull of Megaceroides algericus is unique among fossil and living cervids (Fig. 2). Interestingly enough, the length proportions of the cranium are modified insignificantly: the eye sockets are in normal position for a deer of such a size, the relative length of facial part before eye sockets is the shortest among deer involved in comparison (even some-what shorter than in the insular dwarf Praemegaceros cazioti), however, the difference is not significant (Fig. 4) and the length proportions may be regarded as normal for a deer of this size of subfamily Cervinae. The position of bregma between the 


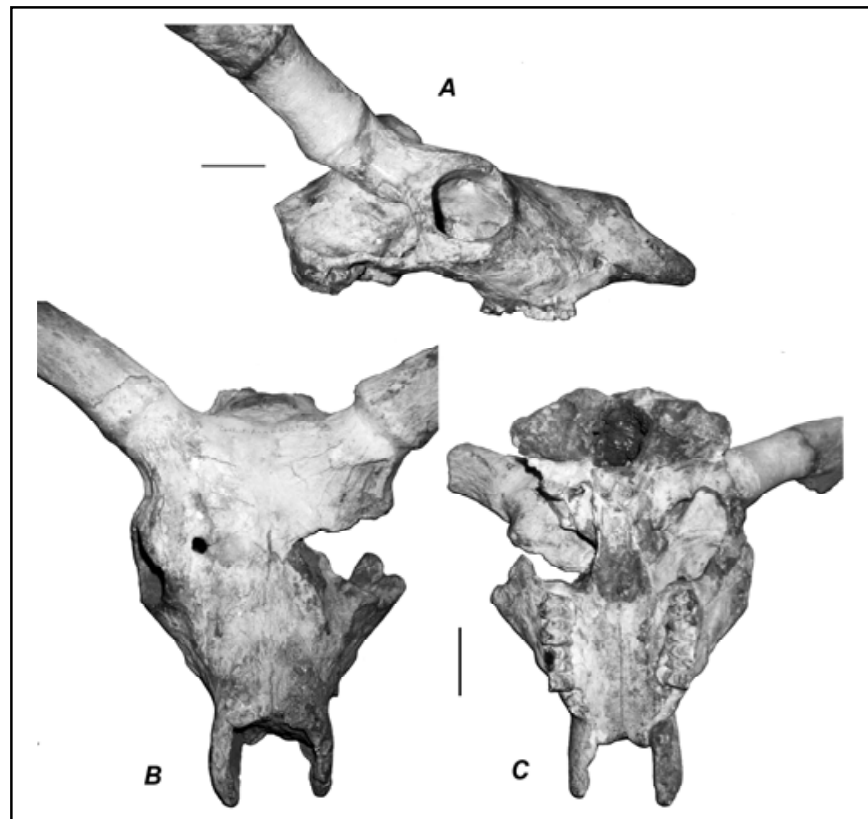

Figure 2. Megaceroides algericus (Lydekker, 1890): the male skull from Guyotville (now Ain-Benian, Algeria) stored in Paris (NMNH, "Collection of Arambourg", no number): A, side view; B, frontal view; C, palatal view. Scale bars: $5 \mathrm{~cm}$.

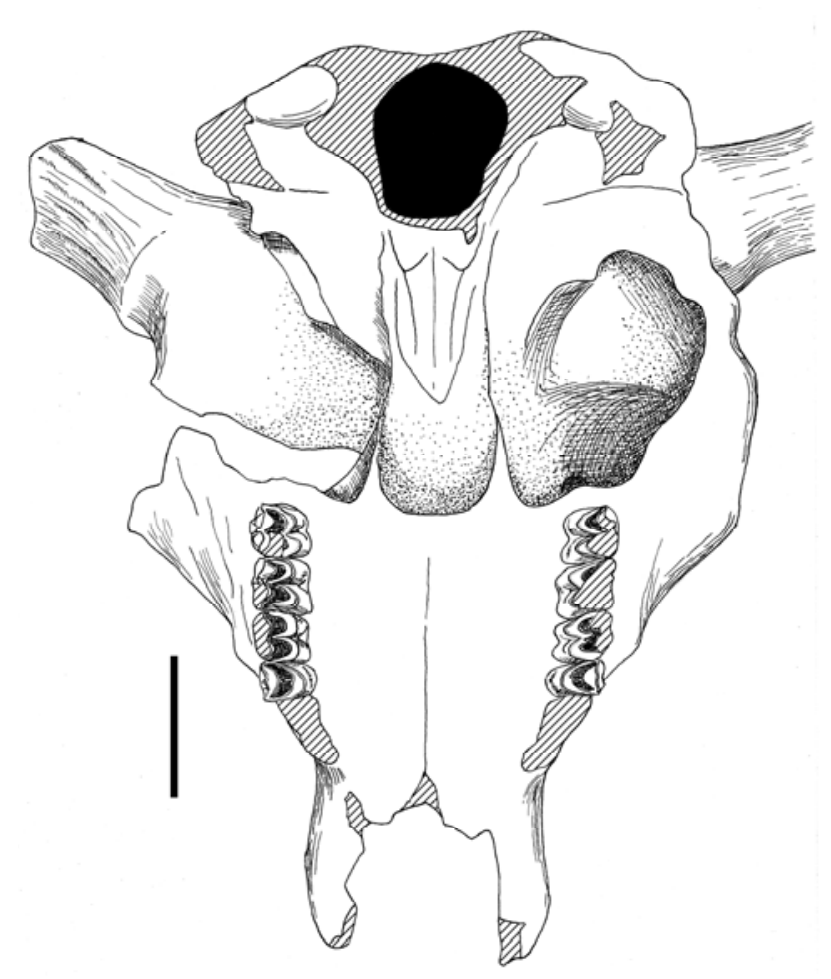

Figure 3. Megaceroides algericus (Lydekker, 1890): the semischematic drawing of the palatal view of the male skull from Guyotville showing the damaged parts (shaded). Scale bar: $5 \mathrm{~cm}$. posterior edges of pedicles and the position of nasion slightly caudally with respect to anterior edges of eye sockets are similar to the morphological condition found in Megaloceros giganteus. The orbito-frontal portion of the cranium is rather short, as in Dama and Megaloceros: the anterior edge of orbit is situated above the $\mathrm{M}^{2}-\mathrm{M}^{3}$ border. The eye sockets are relatively large, as in Dama. The relative length of the upper tooth row with respect to basal length of skull amounts to $29.5 \%$, being fairly close to the ratio found in Megaloceros, Axis and Dama. Nonetheless, the position of upper cheek tooth row shifted toward the anterior represents a specific character of $M$. algericus (Fig. 5). The anterior displacement of the upper tooth row in Megaceroides algericus, apparently, resulted from the strong reduction of the predental length of the skull (distance between $\mathrm{P}^{2}$ and prosthion). The parietal bones are flat. The face profile is straight. The braincase of Megaceroides algericus may be considered as rather flexed: the angle between parietal plane and the facial profile amounts to $135^{\circ}$ and shows an intermediate condition between Dama and Megaloceros (Fig. 6).

The cranial bones are very thick, reminding the cranial hyperostosis described in Megaloceros. However, unlike in Megaloceros, the vomer apparently is not affected by hyperossification (Fig. 3). The zygomatic arches are markedly thin and feeble, contrasting with overall robustness of the skull.

The pedicles are rather long, set obliquely on the skull and some-what deflected toward the rear and the sides. The pedicles are slightly compressed in the antero-posterior direction, however this compression is not as strong as in advanced species of Praemegaceros ( $P$. verticornis, $P$. dawkinsi, and $P$. solilhacus). The frontal bones are very broad (corresponding 


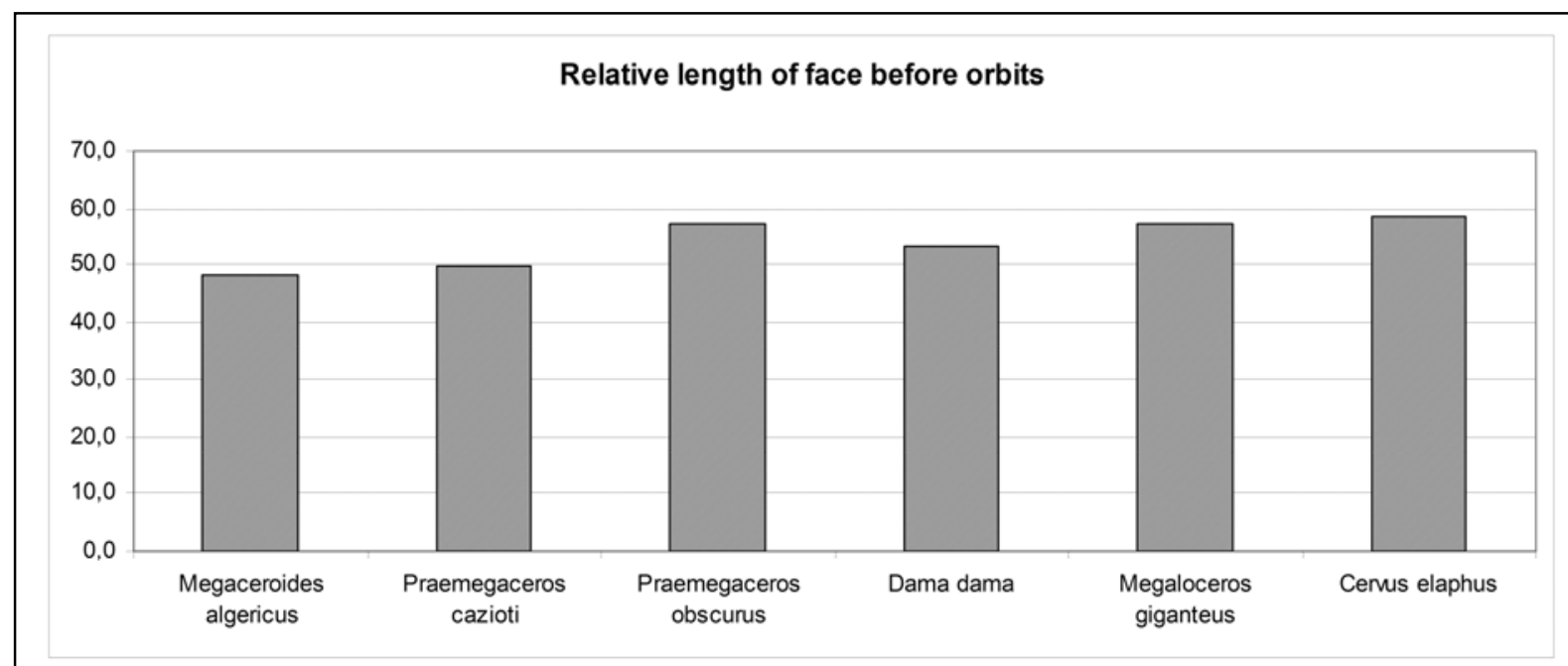

Figure 4. The ratio between the length of face (measured from the anterior edge of orbit to prosthion) to the condylo-basal length of the skull of Megaceroides algericus from Guyotville compared to Dama dama (47.1.1.4, NHML), Praemegaceros obscurus (IGF4024, adapted from Croitor, 2014), Praemegaceros cazioti (adapted from Caloi and Malatesta, 1974), Megaloceros giganteus (M28968, NHML), and Cervus elaphus (Nr. 1927-58, NMNH).

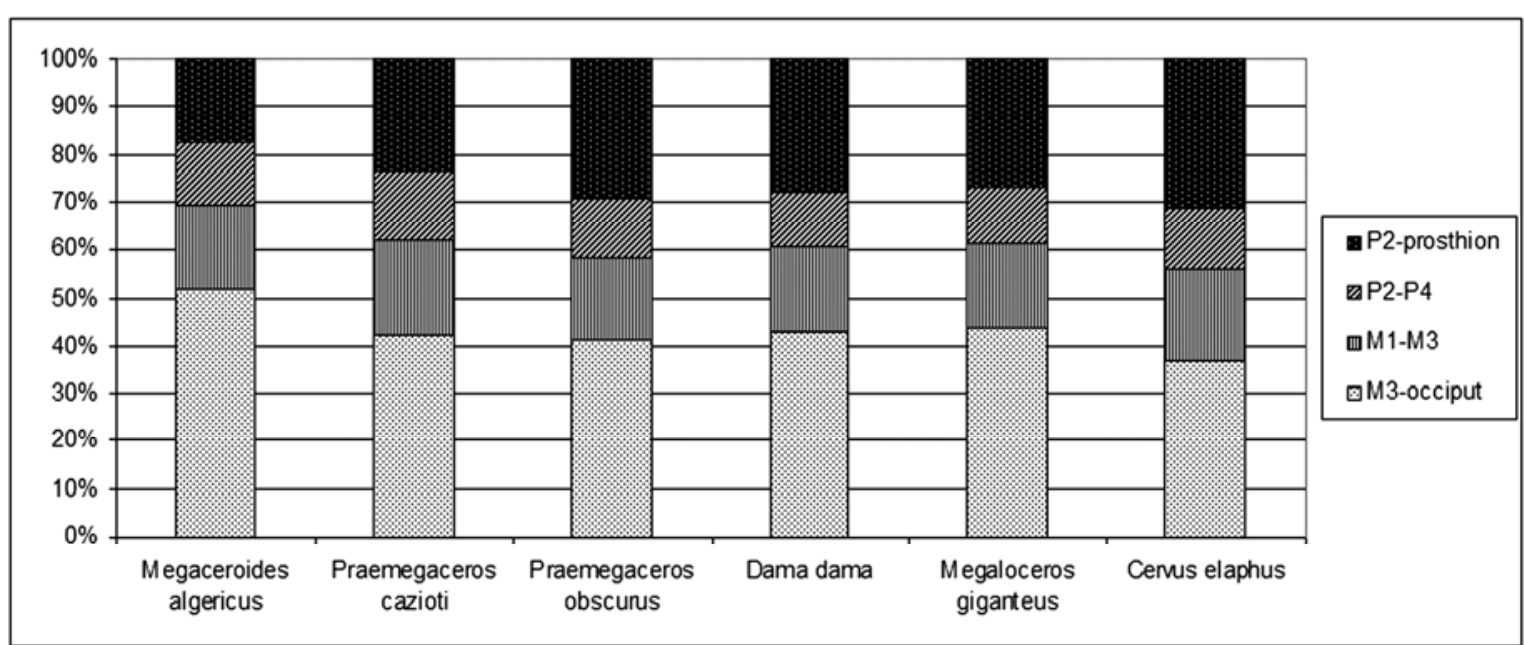

Figure 5. The position of the upper tooth row in Megaceroides algericus from Guyotville compared to large-sized deer (Megaloceros giganteus and Praemegaceros obscurus), an insular dwarfed deer (Praemegaceros cazioti), and medium-sized continental deer (Dama dama and Cervus elaphus). The provenance of specimens involved in the comparison is indicated in the Figure 4.

to the disproportionally broad skull), flat and slightly depressed from the both sides of the frontal suture. The ethmoidal orifices are completely closed. The preorbital fossae are not developed. The nasal bones are relatively narrow and rather long, extending behind the imaginary line connecting the anterior edges of orbits, as in Megaloceros and Dama dama (but not as in Dama clactoniana and Early Pleistocene species of Dama: Croitor, 2014). 


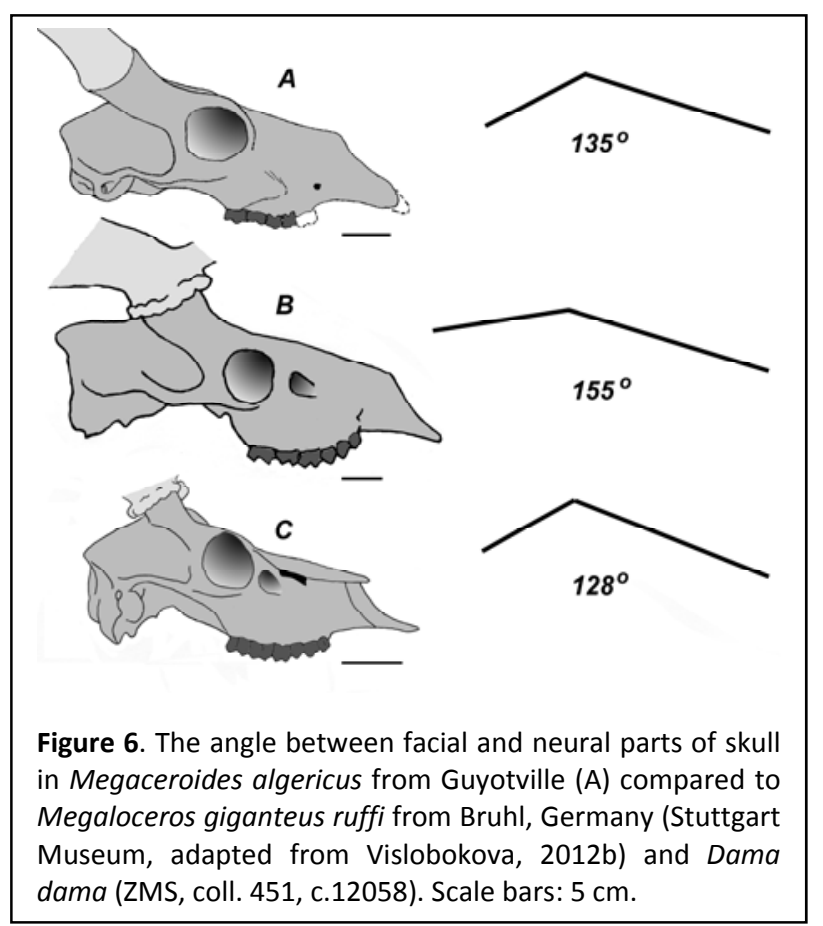
Megaceroides, unlike some Cervinae (Cervus, Rucervus). The foramina ovale are comparatively small, with irregular shape approaching to a triangular outline. The dimensions of foramina ovale are the following: $6.6 \times 6.0 \mathrm{~mm}(\sin ) ; 7.0 \times 5.4 \mathrm{~mm}(\mathrm{dx})$. The nasal bones are extended behind the line connecting the anterior edges of orbits (Fig. 9).

I did not have an opportunity to make a direct comparison of crania of Megaceroides algericus and Sinomegaceros pachyosteus from China, nonetheless, it is useful to compare at least the general shape of Megaceroides algericus with skull of Sinomegaceros from Choukoutien figured by Young (1932). It seems that the skull of Sinomegaceros pachyosteus is broadest at the level of orbits reminding Megaceroides algericus, thou its broadening is not so extreme as we can see in the African deer. One can notice that the skull is broadest in Sinomegaceros pachyosteus at the posterior edge of the orbits, while the skull of Megaceroides algericus is broader at the anterior edge of the orbits. This difference is conditioned, apparently, by the orientation of orbits, which are more forward oriented in Sinomegaceros pachyosteus. One can assume that the noticed difference of orbit orientation represents an adaptation to forested environment in Sinomegaceros pachyosteus. Therefore, the side orientation of orbits in Megaceroides algericus should be regarded as a specific adaptation for open landscape in hoofed mammals allowing a widest possible field of view in order to escape approaching predators. M. algericus is characterized by some-what more flexed braincase than S. pachyosteus (the angle between parietal plane and face profile line measured from the specimen figured by Young (1932) amounts to ca. $145^{\circ}$ ), and both cervids are more advanced in this case than $M$. giganteus characterized by a weak flexion of braincase (see Vislobokova, 1990 for progressive change of this character in Cervidae). S. pachyosteus shows a different position of its orbit with respect of upper tooth row: according to the figure of Young (1932), the anterior edge of orbit is situated above the anterior part of $\mathrm{M}^{2}$ (not above $\mathrm{M}^{2}-\mathrm{M}^{3}$ border as in Megaceroides algericus). Possibly, this difference is caused by relatively diminished size of teeth in $M$. algericus and their oral "migration". 


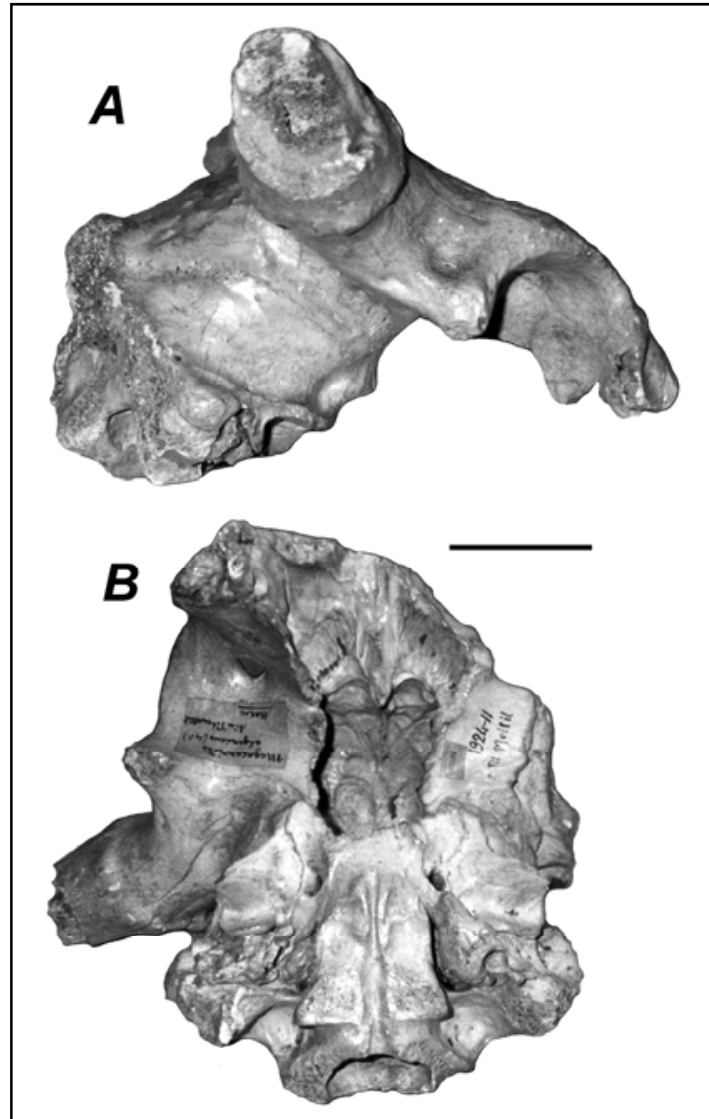

Figure 7. Megaceroides algericus (Lydekker, 1890): the braincase MOC148 (NMNH) from Ain Tit Mellil (Morocco); A, side view; B, basal view. Scale bar: 5 $\mathrm{cm}$.

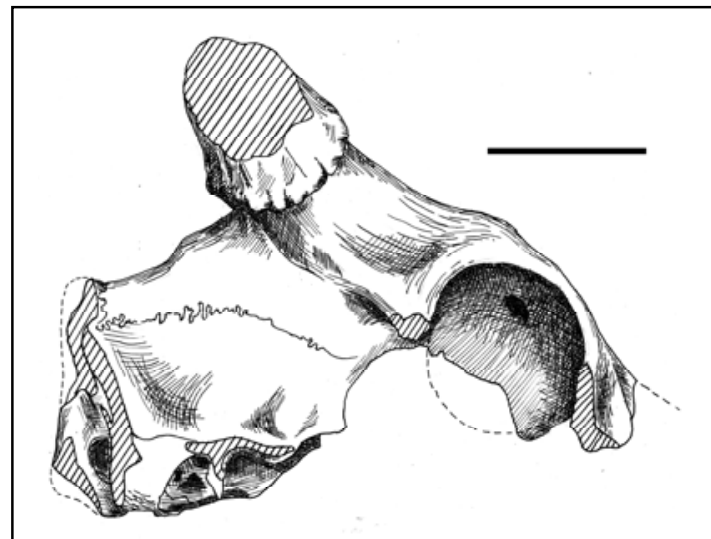

Figure 8. Megaceroides algericus (Lydekker, 1890): the semi-schematic drawing of the specimen MOC148 (NMNH) from Ain Tit Mellil (Morocco) showing damaged (shaded) and missing (dashed line) parts from the side view. Scale bar: $5 \mathrm{~cm}$.
UPPER TEETH: The anterior part of the maxillas is preserved and show that there were no canines (their alveoli are not present) in the specimen from Guyotville. Cheek teeth are relatively small (Tab. 5). The relative size of upper third molar is visibly reduced; therefore $\mathrm{M}^{2}$ is noticeably larger than $\mathrm{M}^{3}$. Only a moderately developed entostyle is present on the lingual side of the upper molars. The entostyle of the upper molars is flattened and well-expressed in the studied additional material. It may extend and partially edge with lingual base of tooth crown; however a continuous (antero-linguo-posterior) large cingulum is not developed. There are no hypoconal spur and other enamel folds on upper molars. The lingual side of the $\mathrm{P}^{4}$ is not split into protocone and hypocone, not even grooved. The lingual side of $\mathrm{P}^{4}$ is bordered with a weak cingulum-like enamel fold.

The fragment of a maxilla with $\mathrm{M}^{2}-\mathrm{M}^{3}$ FIL-169 belongs to an older individual as indicated by the advanced stage of tooth crown wear (Fig. 10). The angle between labial and lingual walls of upper molars (Fig. 10) amounts to $37^{\circ}$, as in Dama dama. The hypoconal fold is present only in $\mathrm{M}^{3}$. Two small enamel folds are found on the external side of anterior hypoconal wing in $\mathrm{M}^{2}$.

It is necessary to indicate that the additional material on upper dentition described in the present paper does not fully correspond to the morphology and measurements of the holotype of Megaceroides algericus. Unlike the

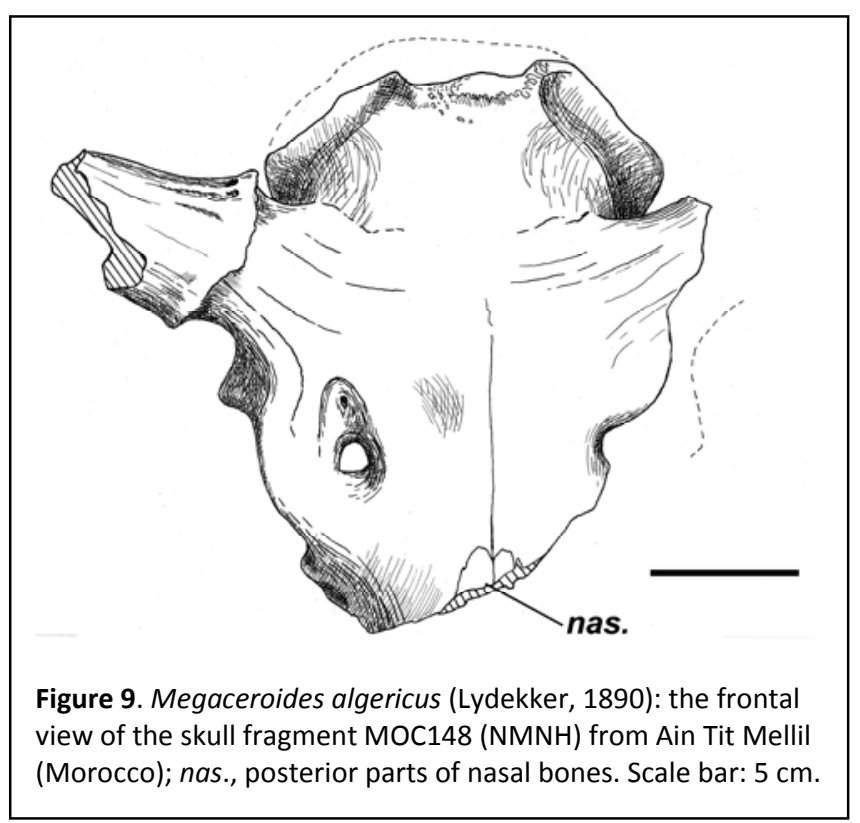



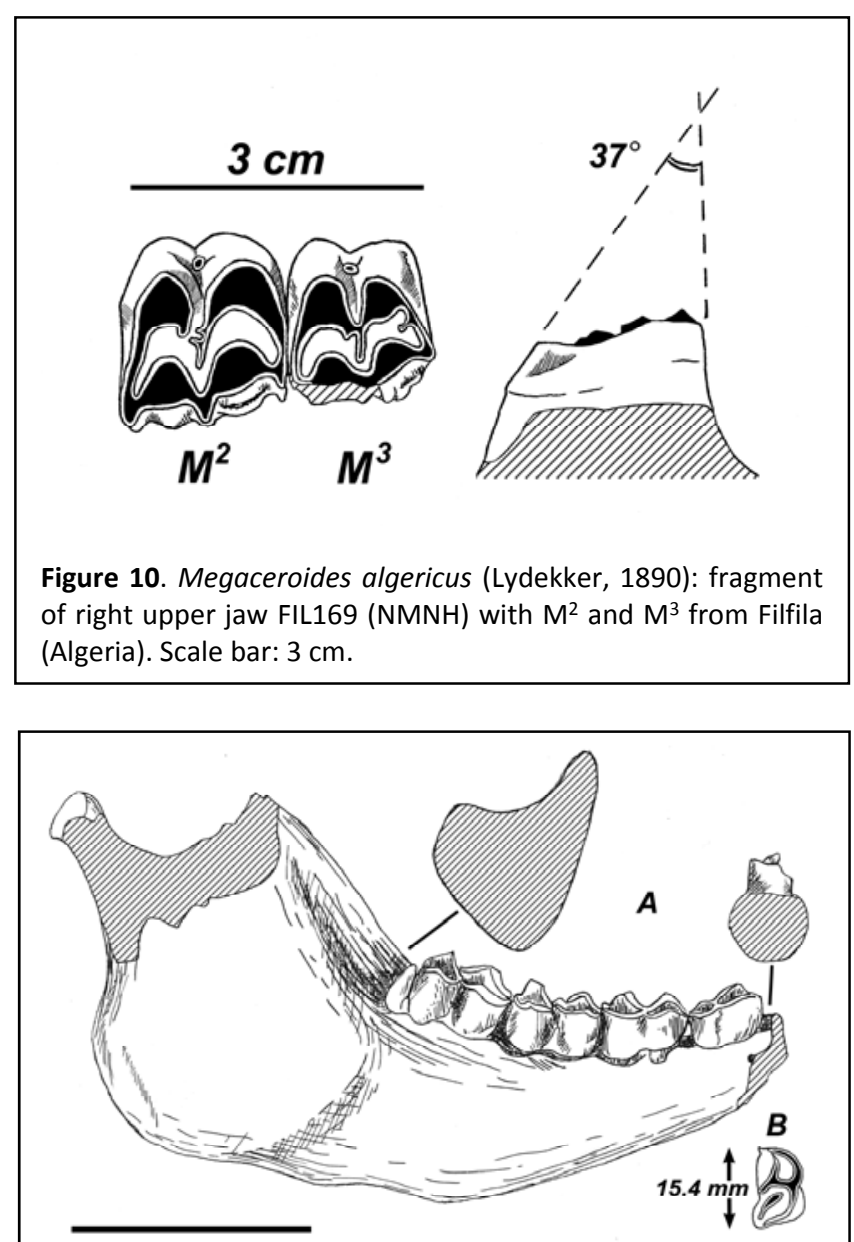

Figure 11. Megaceroides algericus (Lydekker, 1890): the lower mandible ( $d x$, no number, NMNH) from Grotte de la Madeleine (Algeria); $A$, lateral view of mandible with transversal crosssections taken in front of $\mathrm{P}_{4}$ and behind of $\mathrm{M}_{3} ; \mathrm{B}$, occlusion view of $\mathrm{P}_{4}$. Scale bar: $5 \mathrm{~cm}$.

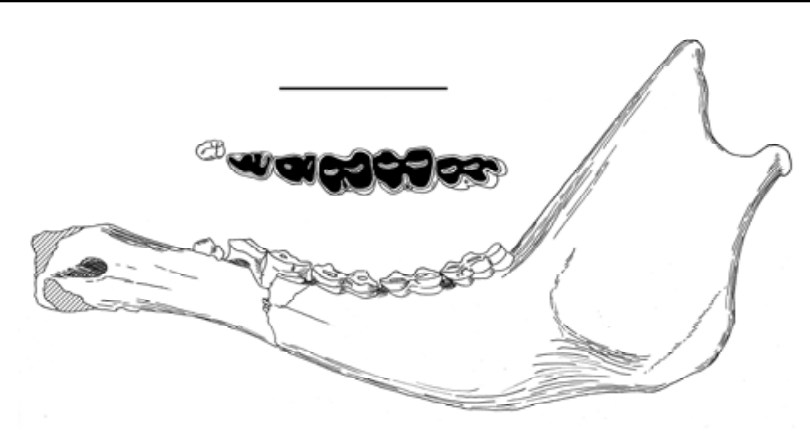

Figure 12. Megaceroides algericus (Lydekker, 1890): the lower mandible (sin, FIL166, NMNH) from Filfila (Algeria), lateral view and dental grinding surface. Scale bar: $5 \mathrm{~cm}$. holotype from Hammam Meskoutin, the additional material of $M$. algericus represents a deer form with some-what smaller upper cheek teeth (length of $\mathrm{M}^{1}-\mathrm{M}^{3}$ tooth series amounts to $54.1 \mathrm{~mm}$ in the specimen from Guyotville against $58.5 \mathrm{~mm}$ in the holotype of $M$. algericus), the cingulum in upper molars of the additional material is not developed, while $\mathrm{M}^{3}$ is significantly reduced in size (this specific size reduction in the specimen from Hammam Meskoutin is not observable). It is not clear yet, if we observe a broad individual variation in dental morphology, or a true evolutionary process (see discussion).

LOWER MANDIBLE: The body of the lower mandible is very low and thick (Fig. 11). The symphysal portion of the mandible is high (Fig. 12, Tab. 6). The diastemal part of the mandible is relatively very short. The anterior portion of the mandible from $M_{1}$ to the symphysis has a cylindrical shape. Behind the $M_{1}$, the mandible becomes higher and more robust. The maximal thickness of mandible is behind $\mathrm{M}_{3}$, in the area of musculus masseter insertion. The available fossil material does not display clear sexual dimorphism of mandibular pachyostosis observed in $M$. giganteus. The juvenile mandible FIL 160 is already pachyostotic, although it is less thick than the mature specimens. The lower side of horizontal part of mandible is convex. The processus angularis is moderately expressed. The ascending part of mandible is sloped backward and forms with the horizontal body of mandible an angle amounting to 60 . The posterior side of the ascending ramus is concave. The coronoid processus is short and cone-shaped. The shape of articulation condyle is cylinder-like. The distance between the cranio-mandibular articulation condyle and the $M_{3}$ is relatively large if compared to the majority of deer involved in the comparative study. This morphological trait is in accordance with the forward displacement of the upper tooth rows. 


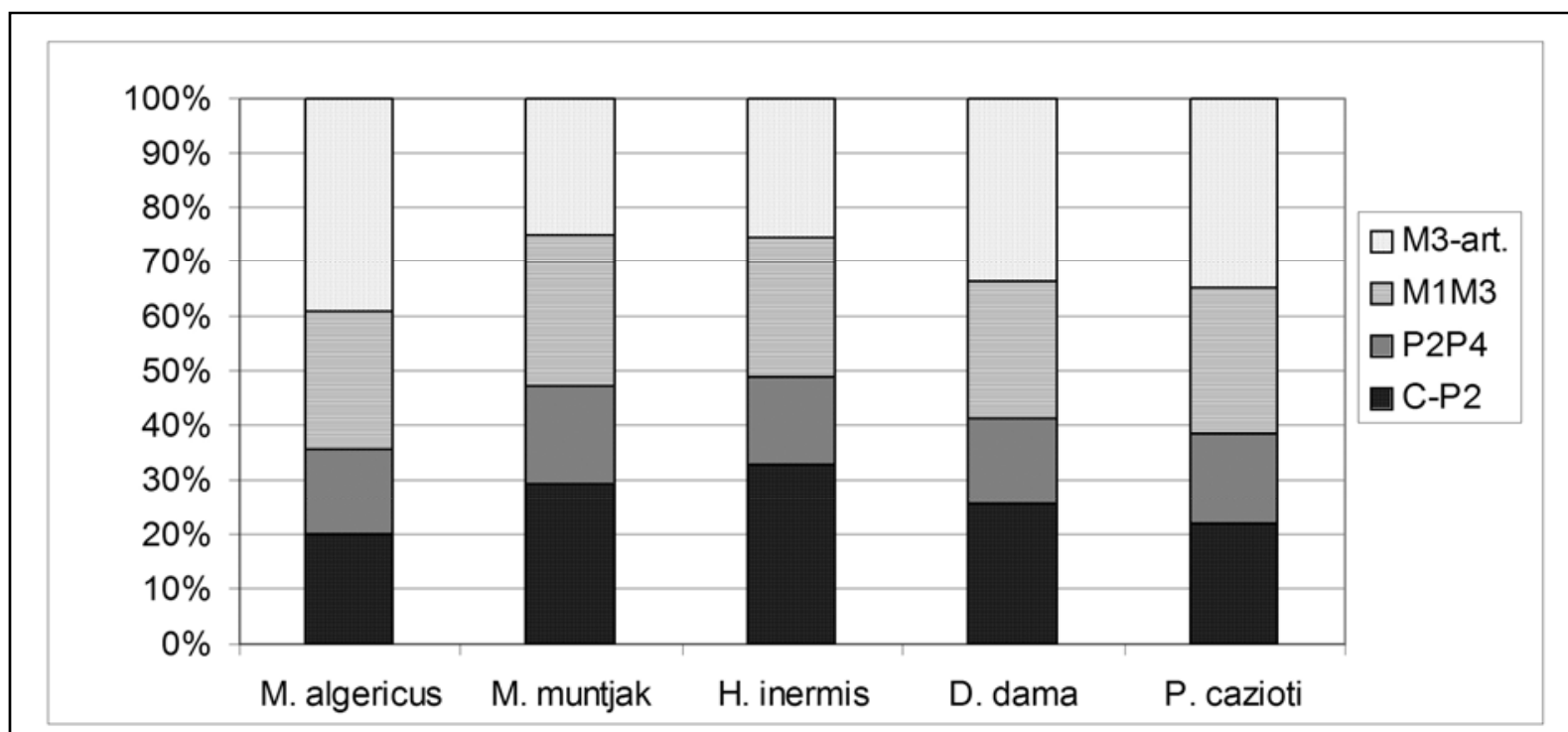

Figure 13. Proportions of lower mandible (FIL166, MNMH) of Megaceroides algericus compared to Muntiacus muntjak (ZMS, c.780), Hydropotes inermis (ZMS, c.1441), Dama dama (ZMS, c.12061), and Praemegaceros cazioti (COS19040, adapted from Croitor et al., 2006); M3-art., the distance between $\mathrm{M}_{3}$ and the mandibular articulation; M1M3, the length of lower molar series; P2P4, the length of lower premolar series; C-P2, the length of diastema (distance measured between lower canine and $\mathrm{P}_{2}$ ).

The lower tooth row is displaced orally due to the very short diastema and obliquely set ascending portion of mandible (Fig. 13).

LOWER TEETH: The crowns of lower cheek teeth are relatively small and rather short and broad (Tab. 7). At the initial stage of wear, protoconid and hypoconid of $\mathrm{P}_{4}$ may not be completely fused (Fig. 11B); however, the fourth premolar usually shows a complete molarization with complete conjunction of protoconid and hypoconid at a more advanced stage of wear. The size of the crown of $\mathrm{P}_{2}$ is much reduced, so it remains untouched even in a deeply worn dentition, as may be seen in the specimen FIL166 (Fig. 12).

The specific proportions of lower tooth row are characterized by relatively reduced size of $M_{3}$, if compared to the larger and broader $\mathrm{M}_{2}$ and $\mathrm{M}_{1}$. The premolar series is comparatively short, however, a broad variation is observed here. The premolar/molar length ratio amounts to $60.5 \%$ in the mandible FIL166, while the same tooth series ratio in the two specimens from Phacocheres amounts to $45.0 \%$ and $52.9 \%$ (Hadjouis, 1990).

DENTAL WEAR: The dental wear in Megaceroides algericus brings interesting details that reveal some earlier overlooked anatomical and paleoecological peculiarities of this species. The entire lower tooth row is worn evenly (with exception of $P_{2}$, which is not worn) in all studied specimens of $M$. algericus, unlike in the majority of deer, which normally show a more advanced wear of $M_{1}$. The statistical processing of mesowear traits is not possible because of the poorly preserved dental material, however, some of observations are interesting and worth mentioning. The character of the tooth row wear varies suggesting a rather broad range of food habits in Megaceroides algericus. Generally, the dental cusps are very low and rounded; nonetheless, the wear surface of the enamel in the majority of specimens available for observation is finely polished, suggesting the predominated dental attrition. However, the grinding surface of the mandible FIL166 is striated by transverse traces of wear caused by a coarse forage material. The direction of wear traces forms an angle of 600 with the tooth row axis. This observation suggests a 


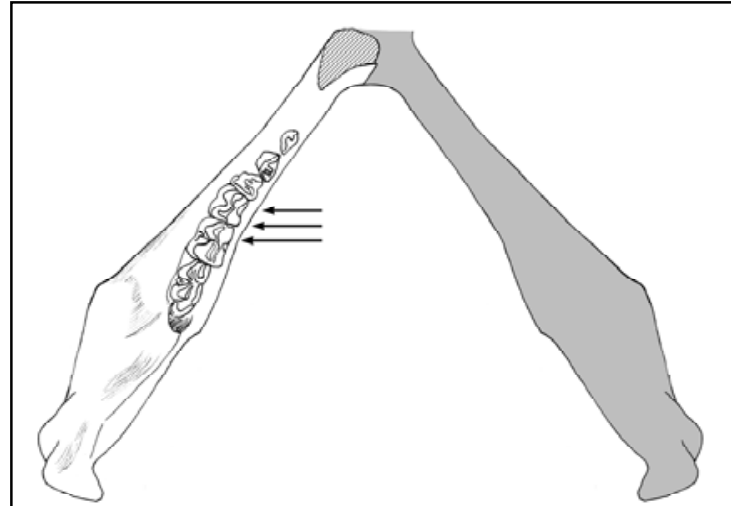

Figure 14. The reconstruction of angle between hemimandibles of Megaceroides algericus (Lydekker, 1890) based on the specimen FIL166 (MNMH). The arrows indicate the direction of the wearing traces caused by coarse forage. comparatively wide angle formed by hemimandibles, which apparently attained 60 (Fig. 14). Such a broad angle between hemimandibles is in accordance with the particularly broad skull.

ANTLERS: The complete antlers of Megaceroides algericus are unknown. The cranium from Guyotville preserved only the proximal parts of the antlers. The left antler is broken just at few centimeters above the burr, while the right antler is broken at $20 \mathrm{~cm}$ above the burr. The antlers are normally developed (the beam diameter is not disproportionally thin with respect to the burr size and the diameter of pedicle) and do not show any sign of "degeneration" reported by Azzaroli (1979). The proximal portion of the right antler beam is straight and directed sideward,

backward and slightly upward. The antler beam is cylinder-shaped and some-what more robust than the supporting pedicle. The antero-posterior diameter of the right antler beam above the burr amounts to $53.0 \mathrm{~mm}$; the latero-medial diameter amounts to $56.0 \mathrm{~mm}$. The same measurements of the left antler amount to $53.3 \mathrm{~mm}$ and $55.5 \mathrm{~mm}$ respectively. The basal tine is not present in Megaceroides algericus. The next middle (or anterior) tine is inserted on the anterior side of the beam. The cross-section of the basal part of the middle tine is ellipse-shaped (its maximal diameter amounts to $40.6 \mathrm{~mm}$, minimal diameter amounts to $22.0 \mathrm{~mm}$ ). The distance between antler burr and the base of the middle tine amounts to $96 \mathrm{~mm}$. The antero-posterior diameter of the antler beam between the burr and the middle tine amounts to $42.4 \mathrm{~mm}$. The height of the middle tine ramification is $140 \mathrm{~mm}$. The antler becomes flattened in the area of the middle tine insertion and the above situated distal portion of antler extends into a palmation: the maximal diameter of antler above the middle tine (where the antler is broken) amounts to $59.3 \mathrm{~mm}$; the minimal diameter at the same level is $41.3 \mathrm{~mm}$.

\section{Discussion}

\subsection{Evolutionary significance of pachyostosis}

The extreme cranial pachyostosis of Megaceroides algericus requires a special discussion here. There are few examples of pachyostosis among mammals. Most of the cases are known in ruminants, and cranial and mandibular pachyostosis in cervids is one of them (Morales et al., 1992). The pachyostosis of limb bones recorded in the Lower Miocene giraffoid Lorancameryx pachyostoticus from Spain represents another phenomenon of bone thickening recorded in ruminants (Morales et al., 1992). Although the character of pachyostosis in Lorancameryx differs histologically and physiologically from the cranial bone thickening in cervids, Morales et al. (1992) regard both cases as different manifestations of the similar physiological and evolutionary process.

Morales et al. (1992) noticed that the limb bone pachyostosis in Lorancameryx occurred in the same geological epoch when several groups of ruminants evolved horns and horn-like cranial appendages. Therefore, according to Morales et al. (1992), the pachyostosis and the bony cranial appendages represented a similar physiological response to certain environmental changes and acted as "bone sinks" 
where excess tissue was stored during the rich in nutrition vegetation growth seasons. According to Morales et al. (1992), the pachyostosis of cervids also could represent a similar secondary metabolic response to exogenic factors, primarily marked seasonality.

The inert bone tissue was deposited in Lorancameryx on the limb bone diaphysis (especially on radius and ulna) every year starting from the subadult age (Morales et al., 1992), while in Megaloceros giganteus the mandibular pachyostosis developed through depositing of additional lamellar bone tissue during the early adult age and no visible changes in the state of pachyostosis were recorded during the subsequent adult

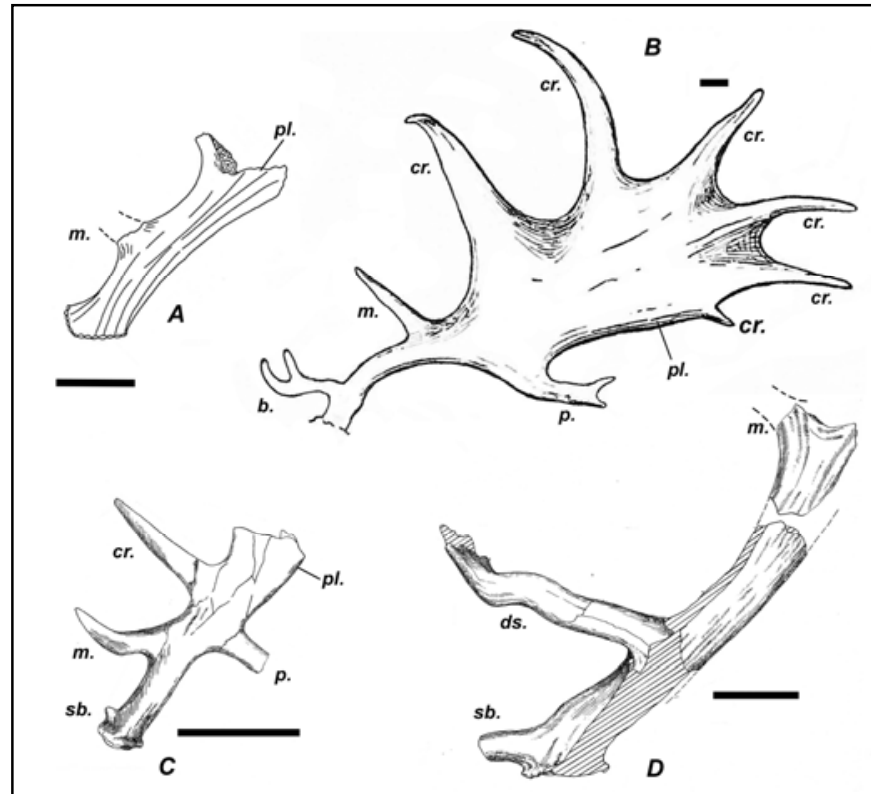

Figure 15. Comparison of antler morphology of giant cervids and their endemic small-sized relatives: A, Megaceroides algericus (Allo. 61.12) from Late Pleistocene of Phacochères (Algeria; reversed image adapted from Hadjiouis, 1990;); B, Megaloceros giganteus from Lough Gur, Limerick (Ireland; adapted from Reynolds, 1929); C, Praemegaceros dawkinsi from Middle Pleistocene of Mundesley, Norfolk (Great Britain; M18706, NHML, reversed); D, Praemegaceros obscurus from Early Pleistocene of Salcia (Moldova, Institute of Zoology of the Academy of Sciences of Moldova, no number); $b$., basal tine; $s b$. , sub-basal tine; $d s$. , dorsal tine; $m$. ., middle tine; $p$., posterior tine; $c r$. , crown tine; pl., palmation. Scale bars: $10 \mathrm{~cm}$. life (Lister, 1994). According to Morales et al. (1992), the tissue of pachyostotic bone in Megaceroides algericus and Sinomegaceros pachyosteus shows the annual cyclic rhythm as in the case of Lorancameryx. Therefore, it seems that the pachyostosis of Megaceroides algericus has a different physiological and ontogenetic background than the pachyostosis of Megaloceros giganteus.

Several authors repeatedly reported the development of mandibular pachyostosis in Praemegaceros and some other large-sized cervid forms (Kahlke, 1958, 1965; Azzaroli, 1979, 1994; Vislobokova, 1990, 2009, 2012a, 2012b, 2013), which, according to the mentioned authors, represent a specific side effect of gigantism in cervids and is regarded as an important taxonomical character distinguishing the phylogenetic branch of giant deer from other phylogenetic branches within the subfamily Cervinae. However, a simple scattered diagram of mandible proportions shows that the mandible shape in large-sized Praemegaceros is very similar to the

morphological condition found in Eucladoceros and Dama (Croitor, 2006). Van der Made and Tong (2008) found signs of mandibular pachyostosis in a wide variety of cervids and assumed that this specific character evolved among cervids several times in parallel and denied its plesiomorphic significance for the phylogenetic group of giant deer. Therefore, the sporadic occurrence of mandibular pachyostosis in various cervid lineages can not be used as a meaningful taxonomic character at the tribe level. The wellexpressed cranial and mandibular pachyostosis is recorded only in very few cervid genera, such as Sinomegaceros from Eastern Asia, Megaloceros from Central and Western Eurasia, and Megaceroides from North Africa. Vislobokova (2009) reports also the mandibular thickening in Late Miocene mediumsized forms of the genus Praesinomegaceros from South Siberia. 
Kahlke (1958) studied the variation of the cross-sections of mandibles in Sinomegaceros pachyosteus from Choukoutien and suggested that the mandible thickening in this deer is a dimorphic character. Kahlke (1958) also assumed that the increased mandible thickening in S. pachyosteus was a gradual evolutionary process. Nonetheless, the mandibular pachyostosis in Sinomegaceros evolved much earlier in another much smaller form with small antlers. Tleuberdina (1982) reported a rather small-sized Late Neogene species (the estimated body mass based on dental measurements did not exceed $50 \mathrm{~kg}$ ) Sinomegaceros robustus from South-East of Kazakhstan. The roe-deer sized S. robustus is characterized by primitive unmolarized $\mathrm{P}_{4}$, small antlers with distal palmations (burr diameters amount to 18.0 and $16.2 \mathrm{~mm}$ ), and pachyostotic lower mandible with almost circular cross-section (Tleuberdina, 1982). According to Shikama and Tsugawa (1962), a certain degree of pachyostosis is recorded also in Sinomegaceros yabei. Three mandible specimens of $S$. yabei, two of which certainly belong to a male, are characterized by a rather moderate degree of pachyostosis similar to the specimens of $M$. giganteus tentatively ascribed to females by Lister (1994) and Croitor et al. (2014).

Lister (1994) supposed that pachyostosis represents an adaptation that enhanced the skeletal calcium store, related to the large size of antlers. Croitor (2006) supported this point of view, noticing that the enhanced mineral storage in head skeleton is an important physiological adaptation permitting the fast growing of large antlers during the relatively short vegetation season. Perhaps, the pachyostosis in Megaloceros giganteus was physiologically connected with such specific for giant deer morphological characters, as an ossified vomer, complete and early obliteration of cranial sutures, diminished size of foramen ovale, and the development of additional enamel folders (cingulum) at the base of molars in some evolutionary most advanced populations of giant deer (Croitor, 2006). Sanchez-Villagra (2010) reported an exceptionally high for Cervidae number of cranial suture fusion in Megaloceros giganteus (20 cranial sutures in giant deer against 10 in modern elk Alces alces), nonetheless, he excluded the simple mechanical adaptation of the advanced bone suture fusion to large and heavy antlers. The high number of suture fusion in giant deer contrasts with the general trend of ruminants toward the diminished number of fused cranial sutures, which is not correlated with body size and apparently represent a specific bio-mechanic adaptation to rumination (Bärmann and Sanchez-Villagra, 2011). Therefore, one can assume that the high number of cranial suture fusion in Megaloceros giganteus represents another specific consequence of pachyostosis. However, Bärmann and Sanchez-Villagra (2011) report the high number of cranial suture fusion also for some other ruminant genera (Ocapia, Tragelaphus, Kobus, and Antilocapra), seeking the explanation in biomechanical factors. Van der Made and Tong (2008) remarked that the function of temporary storage of minerals should be followed by signs of resorption in pachyostotic mandibles. Actually, even non-pachyostotic bones represent a dynamic system constantly undergoing resorption and deposition of minerals and no particular "scars" of resorption on bone tissue could be seen, taking apart the cases of pathology (Alberts et al., 1983). Vislobokoba (2009, 2012b, 2013) regards the cranial pachyostosis of Megaloceros giganteus as a mechanical adaptation (comparable to cranial pneumatization in Rangifer and Bison) correlated with large and heavy antlers and reports a comparatively weak development of cranial pachyostosis in females of giant deer. This hypothesis is questionable for several reasons. The lower mandible is a pending structure that actually is not exposed to the weight load of antlers and can not have any function of weight support in the skull. It is not clear in this case, which biomechanical advantage could bring a pachyostotic mandible, since the low-crowned and relatively small cheek teeth, the low corpus mandibulae and the relatively small area of insertion of musculus massetter in Megaloceros giganteus and Megaceroides algericus suggest that their thick lower mandibles can not 
represent any particular mechanical reinforcement advantage (Croitor, 2006). Besides that, the pachyostosis is recorded also in the small-sized cervid with tiny antlers Sinomegaceros robustus.

It seems that pachyostosis and accessory cranial bone structures in ruminants (here we can mention horns and horn-like cranial appendages) changed their functional significance during the large-scale evolutionary process (Janis, 1982). As cervid antlers, pachyostosis originally could serve as "bone sinks" where the excess bone tissue was stored (Morales et al., 1992). It is interesting that all known pachyostotic cervids belong to the subfamily Cervinae and evolved and lived in the most peripheral and extreme parts of the area of distribution of the subfamily: this is the case of the periglacial cursorial open landscape giant Megaloceros giganteus, the forest dwellers of the genus Sinomegaceros that must be susceptible to the repeatedly advancing arid zones of Central Asia, and Megaceroides algericus that evolved in very unusual for cervids environments (will be discussed below), which strongly modified its skeletal morphology. Those species were exposed to the most stressing seasonal environmental conditions among Cervinae, supporting therefore the hypothesis of Morales et al. (1992). Another argument in the favour of the hypothesis of the similar physiological-evolutionary origin of pachyostosis and antlers in cervids may be sought in the comparison of subfamilies Cervinae and Capreolinae. It seems that the pachyostosis is a peculiar physiological property of the subfamily Cervinae (not tribe Megacerini), which sporadically appears in some specific environmental conditions. Pachyostosis is not known among Capreolinae, however, some members of this subfamily are known to have antlers in females. The best known example is Rangifer tarandus inhabiting the most extreme environmental conditions among Capreolinae, but the occasional presence of small antlers in normally developed females also was reported for Odocoileus and Capreolus (Wislocki, 1954).

Therefore, the cranial pachyostosis in Megaceroides algericus initially represented a specific physiological mechanism characteristic of some lineages of Cervinae that evolved in extreme seasonal environments. The cervid pachyostosis is not correlated with body mass and size of antlers, since it is recorded in smallsized (Sinomegaceros robustus), medium-sized (Megaceroides algericus), and large-sized (Megaloceros giganteus) cervids. However, all known cases of pachyostosis are combined with palmated antlers (the opposite affirmation is not true: many cervids with palmated antlers have no pachyostosis), suggesting that palmated antlers have not only social evolutionary significance, as it was suggested by Geist (1998), but also a specific environmental and physiological background.

\subsection{Paleoecology of Megaceroides algericus}

Regarding the pachyostosis of Megaceroides algericus, I would like to point out some of its peculiar traits distinguishing from the pachyostosis in Megaloceros. Not all parts of skull in Megaceroides are equally pachyostotic: zygomatic arches and anterior part of mandible are comparatively weak and not reinforced by pachyostosis. The weak (or better to say, normal) zygomatic arches are needed to ensure the movements of lower jaw and probably that is why they are not affected by distorting pachyostosis. The bony rim of orbits and very broad forehead are particularly pachyostotic and ensure protective shelter for weak zygomatic arches. Other part of the skull (rostrum, braincase) and the posterior part of mandible are also strongly pachyostotic and create a sort of bony helmet. At present, it is difficult to affirm if the cranial pachyostosis in Megaceroides algericus is a matter of sexual dimorphism. The only two known wellpreserved skulls belong to males. The rather small series of available lower mandibles does not show any visible dimorphism. Ontogenetically, the pachyostosis of Megaceroides algericus is also specific. Taking into account the juvenile mandible FIL160 from Filfila and the pachyostotic mandible with deciduous teeth 
from the grotto of Chenoua (Algeria) figured by Arambourg (1938: fig. 8A), the additional bone tissue depositing started in Megaceroides algericus from the early juvenile age, unlike in Megaloceros giganteus. As it already was mentioned above, the tissue of pachyostotic bone in Megaceroides algericus shows an annual cyclic rhythm and therefore increases with age at least during some period of the animal's life (Morales et al., 1992).

Whatever was the initial significance of the cranial pachyostosis, it seems that it acquired a new function in Megaceroides algericus. Apparently, the unusual cranial specialization of $M$. algericus is a result of adaptation to an ecological niche, which was unavailable for ecologically highly competitive (fide Geist, 1998) African bovids. There are no morphological analogies among modern species of deer or other ruminants that could be helpful in the paleoecological interpretations of $M$. algericus. The anterior part of the mandible, the zygomatic arches and the dentition remain comparatively weak, contrasting with the pachyostotic bones of cranium and the posterior part of the mandible. The processus coronoideus of the lower jaw is short and cone-shaped and the area of insertion of musculus masseter is rather small. Taking in account the studies of cranio-dental adaptations in ruminants (Caloi and Palombo, 1995; Janis, 1995; Palombo, 2005), the enlisted characters suggest that $M$. algericus had quite low mastication abilities and was not adapted to process a hard fibrous forage material. The rather weak mastication ability is suggested also by the oral (toward the anterior) shift of cheek tooth row that results a decrease of power moment. The flat and broad skull with broad muzzle of $M$. algericus vaguely reminiscent of specific cranial shape of such semiaquatic herbivorous mammals as hippopotamuses. The weak mastication abilities and small lowcrowned cheek teeth suggest the semiaquatic or periaquatic habits of $M$. algericus and specialization to forage on soft water herbage. The reduced preorbital fossae could be another adaptation to a periaquatic habitat, since the peorbital fossae are very small in modern Chinese water deer Hydropotes inermis (Flerov, 1952). Another specific morphological character of Megaceroides algericus may be found in the images of this animal from the Paleolithic art. Camps (1992) published several Paleolithic images of this deer that show unusual for a cervid very long tail. Among modern cervids of similar body size, the relatively long tail is characteristic of Elaphurus davidianus specialized to humid swamp habitats (Flerov, 1952).

The assumption of semiaquatic or periaquatic habits of $M$. algericus is supported by the finely polished by attrition (Fortelius and Solounias, 2000) grinding surfaces of cheek teeth in the majority of studied specimens. However, the low dental cusps and the grinding surface of lower mandible FIL166 striated by transversal traces of wearing caused by a coarse forage material suggest that the animals were regularly exposed to a stressing shortage of forage, apparently, during the dry seasons, as is was shown, for instance, for modern plains zebra Equus burchelli (Kaiser and Schulz, 2006). The regular exposure to unfavorable seasonal conditions is also supported by the cyclic rhythm of pachyostosis development noticed by Morales et al. (1992).

Cranial helmet-like pachyostosis in M. algericus could have a function of passive defense against such water predators as, for instance, crocodiles, which represent the most frequent danger in African periaquatic biotopes (Croitor, 2014). Crocodiles were present in the area of distribution of Megaceroides algericus in the past and survived in the region until the middle of XX century (Brito et al., 2011). The head of foraging deer is the important part of body most exposed to predator's attacks. The early ontogenetic development of pachyostosis in $M$. algericus supports this hypothesis, since this character must be vitally important for juveniles too. The thick cranial and mandibular bones must protect animal's head from deep lethal wounding and therefore increase chances of animal to escape from a predator. The cranial pachyostosis inherited from forerunners by Megaceroides should be regarded here as a good example of 
preadaptation that was maintained by natural selection in new conditions as the adaptation of passive defense. The robust radius and ulna described by Pomel (1893) could be a part of such adaptation permitting to the deer to resist the attempts of a crocodile to drag its prey under the water.

Abbazzi (2004), taking into account the brachyodont dentition and shallow mandibular body combined with sideward oriented antlers and large tympanic bullae, arrived to a rather contradictory conclusion that the small-sized M. algericus was an open-landscape browser (see Janis, 1995 and references therein). Although Abbazzi (2004) reports the large size for upper and lower teeth, this is not the case: the cheek teeth of $M$. algericus are relatively small, marked by particular size reduction of premolars and third upper and lower molars $\left(\mathrm{M}^{3}\right.$ and $\left.\mathrm{M}_{3}\right)$. Nonetheless, the brachyodont first and the second upper and lower molars $\left(M^{1}, M^{2}, M_{1}\right.$, and $\left.M_{2}\right)$ are relatively broad, representing, in my opinion, a sort of grinding millstones for soft water plants.

The composition of faunas associated with $M$. algericus ecologically is quite heterogenous and may be regarded as a mammal assemblage that inhabited an ecotone near water body. The faunas from Ain Tit Mellil (Morocco) and Filfila (Alger) contain semiaquatic species like Hippopotamus amphibius, forest dwellers like Sus scrofa algeriensis, woodland species like Bos primigenius, Taurotragus, and open landscape species Connochoetes taurinus, Crocuta spelaea, Camelus sp. (Arambourg, 1939; Hadjiouis, 1990).

\subsection{Systematic position of the genus Megaceroides}

The systematical place of such an odd and very specialized species as Megaceroides algericus within Cervinae is not easy task. However, even if the cranial morphology of M. algericus shows some highly specialized traits, the correct assessment of plesiomorphic and apomorphic characteristics allows for revealing the phylogenetic relationships of the North African endemic lineage and its systematical position.

Megaceroides shows the most significant morphological differences from the genus Cervus and allied forms. Unlike deer of the Cervus group (genera Cervus, Hyelaphus, Rusa, and Pannolia), M. algericus is characterized by a broad bell-shaped basioccipitale (as modern Axis, Rucervus, Dama, and the majority of extinct genera of Western Eurasia), relatively large and rounded bulla tympani (as Dama), missing upper canines (as Dama and Megaloceros), and long nasal bones that extend behind the anterior edges of orbits. Excluding pachyostosis as a peculiar specialization, one can notice that Megaceroides possess an advanced cranial morphology if compared to Cervus and allied to Cervus genera of Southern and Eastern Asia. The cranio-dental morphological differences suggest that the lineages of Megaceroides and Cervus diverged as early as Late Miocene.

Obviously, Megaceroides does not belong to the phylogenetic branch of the genus Praemegaceros as it was suggested by Azzaroli (1979) and Vislobokova (2013). Unlike Praemegaceros, Megaceroides is characterized by the relatively longer braincase (a primitive character), the cylinder-shaped pedicles (not compressed antero-posteriorly, or dorso-ventrally, if we take in consideration their strong inclination toward posterior and sidewards on the skull, as in some advanced species of Praemegaceros), the cranial and mandibular pachyostosis, and the long nasal bones (Croitor, 2006). The long nasal bones of Megaceroides extended behind the imaginary line connecting anterior edges of orbits represent a good taxonomic character, but are of little interest for the systematical and phylogenetic study, since, probably, they represent here an advanced apomorphic character. However, the relatively long braincase of Megaceroides is an important primitive character that rules out a direct phyletic relationship with 
geologically older, but more advanced in this case Praemegaceros. The cylindrical shape of pedicles in Megaceroides also suggests that this genus is not related with the advanced Middle Pleistocene species of Praemegaceros ( $P$. verticornis and $P$. solilhacus), which evolved the bio-mechanically more advantageous dorso-ventrally compressed and latero-medially extended pedicles that acted as a reinforced support with increased area of cross-section for large and heavy antlers (Croitor, 2006). The peculiar dorso-ventrally compressed shape of pedicles is maintained even in the secondary dwarfed $P$. dawkinsi with diminished antlers.

The cranial and dental morphology of Megaceroides and Dama shows some more resemblances (Tab. 8). Megaceroides shares with Dama the broad bell-shaped basioccipitale, the large orbits, the large rounded bulla tympani, the flexed braincase, the long nasal bones (however, this character is also apomorphic in Dama: Croitor, 2014), the missing upper canines, and the similar proportions of lower tooth row: PP/MM in Megaceroides varies between $45.0 \%$ and $60.5 \%$, while in modern Dama dama varies between $46.0 \%$ and $61.6 \%$ (Croitor, 2014). Unlike Dama, the braincase of Megaceroides is some-what less flexed; the parietal and frontal bones are flat; the pachyostosis is strongly pronounced (it is completely absent in Dama); the rather long pedicles are set obliquely on the skull (not short and vertically oriented as in Dama); the ethmoidal vacuities are completely closed; and upper molars are supplemented with a variable lingual cingulum. Such cranial characters as the less flexed braincase and obliquely set frontal pedicles define $M$. algericus as a more primitive cervid form than fallow deer. The closed ethmoidal vacuities in M. algericus, apparently, resulted from the pachyostosis of face bones.

Megaceroides and Megaloceros share the developed cranial pachyostosis, the bell-shaped basioccipitale, the missing upper canines, the presence of a variable cingulum in upper molars, and long nasal bones extended behind the imaginary line connecting the anterior edges of orbits (Tab. 8). The shape and relative length of the braincase, the position of the antler pedicles, developed cingula in upper molars, and the cranial hyperostosis of Megaceroides algericus suggest its greater affinity with Megaloceros giganteus. Unlike Megaloceros, Megaceroides is characterized by enlarged rounded bulla tympani, a flexed braincase, a lacking basal tine, and relatively larger orbits with respect to the condylo-basal length. However, the relatively large orbits may be a secondary effect caused by the shortened splanchnocranium. It seems that proportions of the lower tooth series in Megaceroides (PP/MM - 45.0\%, 52.9\%, 60.5\%: Croitor, 2014) tend to be more advanced than in Megaloceros giganteus from Ireland (PP/MM - 53.6-61.1\%, based on the sample stored in $\mathrm{NHML}$ ), and significantly more advanced (according to evolutionary trends in Cervidae described by Vislobokova, 1990) than in the primitive form of Megaloceros giganteus from Bisnik, Poland (PP/MM - 61.9-65.6\%: Croitor et al., 2014). The presented here analysis of cranial characters of various Eurasian cervids confirms the old assumption of Joleaud (1914) on intermediary morphological and systematic position of Megaceroides between Megaloceros and Dama. The peculiar combination of cranial and dental characteristics of the African deer confirms the reasonability of the elevation of Megaceroides at the generic level proposed by Arambourg $(1932,1938)$.

Molecular phylogenetic study has revealed that the fallow deer is the closest to Megaloceros giganteus modern cervid, although the evolutionary divergence between Megaloceros and Dama has occurred very early, 4-5 Myr (Lister et al., 2005) or even 10.7 Myr ago (Hughes et al., 2006). The close phylogenetical relationship between $M$. giganteus and $D$. dama is also supported by some shared characteristics of the cranial morphology: both species share a relatively long braincase, long nasal bones (synapomorphy), a relatively short orbito-frontal portion of skull (the anterior edge of the orbit is situated above $\mathrm{M}^{2}$ ), missing upper canines, and a similar shape of the broadened basioccipitale at the level of the pharyngial 
tuberosities. Pfeiffer's (1999) suggestion on close relationship between the giant deer and the red deer based on the postcranial morphology analysis is disputable. The use of postcranial morphology in phylogenetic reconstructions is unsafe since limb bones are greatly influenced by various environmental and biomechanical factors like landscape character, ground surface character, type of locomotion, body mass, social behavior, etc. (Köhler, 1993). The missing studies analyzing plesiomorphic and apomorphic characters of postcraial skeleton represent the main methodological problem in this case. Therefore, a cluster analysis of postcranial morphology rather reveals ecological and biomechanical similarity than a genuine phylogenetic relationship. The molecular phylogeny research carried out by Kuehn et al. (2005) suggests a close relationship between giant deer and red deer, but, according to Hughes et al. (2006), these results come from a wrong determination of fossil specimens or from contamination during the DNA amplification process. The obtained by Kuehn et al. (2005) genetic evidence on close relationship between giant deer and red deer is "almost certainly the result of contamination" (A. Lister, pers. comm.).

The palmed antlers of Megaceroides algericus with the lacking basal tine (Fig. 15) are of minor significance for the present study, since the palmations may have evolved independently in each phyletic lineage, while the basal tines have tend to reduce in cervid forms with secondary reduced body size, as for instance in Praemegaceros dawkinsi and numerous dwarfed insular species (Azzaroli, 1961; Azzaroli, 1979; Caloi and Malatesta, 1974; Croitor, 2006; Croitor et al., 2006).

Azzaroli (1953), Thomas (1979) and Hadjiouis (1990) noticed that the shape of the lower mandible and skull of Megaceroides algericus is similar to the mandibles of Simomegaceros pachyosteus from Choukoutien (China). At least superficially, the skull shape of Sinomegaceros pachyosteus with its little flexed braincase, broad orbito-frontal part, and short splanchnocranium seems to be a less accentuated version of Megaceroides algericus. Megaceroides is characterized by the presence of a well-developed middle tine, which normally is lacking in Sinomegaceros (Shikama and Okafuji, 1958; Shikama and Tsugawa, 1962; van der Made and Tong 2008). Van der Made and Tong (2008) regard the absence of the middle tine as an essential diagnostic character of Sinomegaceros that is shared with Arvernoceros. However, a small knob-like vestige of the middle tine is present in some specimens of $S$. pachyosteus (Kahlke, 1958), therefore, caution is needed. The area of distribution of the genus Sinomegaceros in Eastern Asia was latitudinally limited to between $50^{\circ}$ and $25^{\circ}$. According to Vislobokova (2012a, 2012b, 2013) Sinomegaceros was a southern ecological counterpart of Alces and, therefore, could not disperse to North and West because of the ecological competition with Alces. Van der Made and Tong (2008), taking in account the combination of dental, antler, cranial, and postcranial characters in large-sized deer from West and East of Eurasia, exclude the possibility of migrations of large-sized deer from the eastern part of Asia to the West. Considering this, the cranial shape affinity between Sinomegaceros and Megaceroides could be a curious example of convergence. Ultimately, only an extensive morpho-functional study of the cranial and whole skeletal morphology of Sinomegaceros may clarify the nature of this convergence.

\subsection{Taxonomical context of Megaceroides algericus}

The taxonomical significance of rather variable dental morphology of Megaceroides algericus, such as the varying cingulum in upper molars and the broad variation of tooth row proportions, is still unclear. Possibly, we are dealing in this case with chronological forms of the endemic North African deer: an older larger form from Hammam Meskoutin with strong cingulum and normally developed $\mathrm{M}^{3}$, and a more specialized descent form with smaller dentition, reduced cingulum and marked reduction of $M_{3}$ and $M^{3}$. One can assume that the thick-jawed deer described by Pomel (1892) and figured in the later publication 
(Pomel, 1893) represents a late form distinguished by relatively smaller $\mathrm{M}_{3}$ (Tab. 7). If this is true, Pomel's $(1892,1893)$ name Cervus pachygenys proposed for the African Neolithic cervid form with pachyostotic mandibles and upper molars without cingulum could be used at list as a subspecies Megaceroides algericus pachygenys (Pomel, 1892). In this case, the lower mandible from Berrouaghia (Algeria) described and figured by Pomel $(1892,1893$ : pl. VII-VIII) should be regarded as the holotype of $M$. algericus pachygenys.

The taxonomical position of the genus Megaceroides needs to be clarified too. Viret (1961) proposed to place the giant deer in a separate tribe Megacerini based on the genus Megaceros Owen, 1844. This point of view is accepted and defended by Vislobokova (1990, 2009, 2012a, 2012b, 2013) and di Stefano and Petronio (2000-2002). According to Lister (1987), the genus name Megaloceros Brookes, 1828 has priority over Megaceros Owen, 1844 and this viewpoint was accepted uncritically. Somewhat later, Lister (1994) substituted Megacerini Viret with Megalocerini and supposed that Dama could be the only survived genus of this tribe. Abbazzi and Masini (1997) quoted Lister's tribe name as Megalocerini Viret, 1961. Vislobokova (2009) accepts the genus name Megaloceros, however she continues to use the tribe name Megacerini based on Megaceros. Grubb (2000) pointed out that Megacerini Viret, 1961 is a junior synonym of Megalocerotinae Brookes, 1828. Therefore, the correct name of the tribe should be Megalocerotini Brookes, 1828. According to Grubb (2000), the genera Praemegaceros, Megaceroides, Megaloceros, and Sinomegaceros belong to the tribe Cervini Goldfuss, 1820, therefore Megalocerotini Brookes, 1828 is a synonym of Cervini Goldfuss, 1820.

Vislobokova (1990, 2009, 2012a, 2012b; 2013) considers that the tribe of giant deer includes eight genera: Megaloceros, Praemegaceros, Sinomegaceros, Praesinomegaceros, Praedama, Orchonoceros, Arvernoceros, Neomegaloceros. In my opinion (Croitor, 2006), the quoted list of genera represents a rather eclectic group including forms that belong to several different phylogenetical stocks, as well as poorly known cervid forms, such as Neomegaloceros gracilis and Praedama savini (see the discussion below).

Radulesco and Samson (1967) and Azzaroli and Mazza, $(1992,1993)$ regard Eucladoceros as a primitive forerunner of Praemegaceros, seeking support for this hypothesis in the homologous general construction of antlers. Moreover, Praemegaceros shares essential cranial characteristics and antler morphology with Eucladoceros and the direct phylogenetical relationship between those two genera is accepted by many authors (Radulesco and Samson, 1967; Azzaroli, 1979; Azzaroli and Mazza, 1993; Abbazzi, 2004; Croitor, 2006, 2014). Earlier, I proposed to include Praemegaceros and Eucladoceros together with Orchonoceros in the tribe Eucladocerini (Croitor, 1997), but, according to the current state of knowledge, this taxon also falls under synonymy of Cervini Goldfuss, 1820.

The assumed direct phylogenetical relationship between Megaloceros and Praedama is based on a single character, the flattened basal tine (Azzaroli, 1953; Vislobokova, 1990; Van der Made and Tong, 2008), which could be just an apomorphic character. The fine series of antler material from Forest Bed (stored in NHML) and the complete antler from Suessenborn, Germany (Kahlke, 1969: tab. XXXIV) show a series of characters that suggests a significant morphological distance between Praedama savini and Megaloceros giganteus: unlike giant deer, the antler base in Praedama savini is characterized by a specific quadrangular cross-section, while the compressed from the sides whole antler and the dichotomous pattern of bifurcation of crown tines rather reminds Eucladoceros (Croitor, 2014). The flattened proximal part of basal tine of Praedama savini (the complete basal tines are unknown) that is regarded as a good argument for close relationship between Megaloceros and Praedama, is characteristic of Eucladoceros dicranios too. The dental and mandibular remains of Praedama from Cueva Victoria do not show any trace of cingulum 
in upper molars and have no clearly expressed mandibular pachyostosis (van der Made, 2014). The skull morphology of Praedama is unknown; therefore, well-founded arguments on phylogenetic relationships of this endemic European genus for the present moment are missing. We need more fossils and better arguments that will help to reveal the systematic position and phylogenetic relationships of Praedama.

Arvernoceros ardei is another species, which was regarded as a forerunner of $M$. giganteus because of its palmated basal tine and associated with its antlers isolated upper molars with cingulum (Heintz, 1970). The very large-sized deer Arvernoceros verestchagini from the Early Pleistocene of Eastern Europe and Greece maintained a rather simple antler construction, a simple unmolarized lower fourth premolar, and lacks a cingulum, hyperostosis, and other characters that undoubtedly could indicate a relationship with Megaloceros (Croitor and Kostopoulos, 2004). The general pattern of antler construction of Arvernoceros recalls that of Sinomegaceros (van der Made and Tong, 2008) and modern Rucervus (Croitor, 2009). According to genetic data, Rucervus duvaucelii has a detached position among modern Cervinae, having diverged very early (Late Miocene) from the main group of Old World deer together with Axis axis (Pitra et al., 2004).

The last problematic deer, Neomegaloceros gracilis from the Late Miocene of Ukraine was proposed by Korotkevich (1971) as a forerunner of Praemegaceros verticornis since its antler is characterized by a distal palmation and an additional tine, which was interpreted as homology to the posterior tine in Praemegaceros. The first tine of Neomegaloceros is situated very high on the anterior side of the beam. The antler beam in Neomegaloceros is not curved in the areas of first and posterior tines as in Praemegaceros. The general antler shape of Neomegaloceros does not show any similarity with antlers of Praemegaceros. The distal palmation of the antler is regarded by Korotkevich (1971) as an important character proving the direct phyletic relationship between Neomegaloceros and Praemegaceros. However, the palmed antlers appear only in the most advanced forms of Praemegaceros, while earlier forms Praemegaceros obscurus, $P$. pliotarandoides, and $P$. verticornis dendroceros bear antlers without palmations (Azzaroli and Mazza, 1992, 1993; Croitor, 2006). The so-called "posterior tine" appears in the several cervid lineages, represented by such genera as Rangifer, Megaloceros, Praedama, and some Sinomegaceros. It seems that the "posterior tine" developed several times independently in cervid forms adapted to open environments and, possibly, had a function of removing the flying parasites from the back in the rutting males, thus increasing their combat capacities. Neomegaloceros rather is a junior synonym of Cervavitus and belongs to the subfamily Capreolinae Brookes, 1828 (Croitor, 2006; 2014).

Therefore, the tribe of so-called giant deer sensu lato proposed by Vislobokova $(1990,2009,2013)$ is a polyphyletic group that includes various lineages not only from the subfamily Cervini, but also from the subfamily Capreolini. Most of the cervids included by Vislobokova $(1990,2009,2012 a, 2012 b ; 2013)$ in the tribe of giant deer represent the peculiar eco-evolutionary type or "constellation" (if we apply the term used by Geist, 1998) of open landscape giants with very large antlers (Megaloceros, Praemegaceros) and forest/woodland giants with smaller antlers (Arvernoceros, Sinomegaceros) approaching to the ecoevolutionary type of modern Alces alces.

The tribe Megalocerotini Brookes, 1828 sensu stricto should be restricted only to the genera Megaloceros, Megaceroides, and Dama, however, it is difficult in this case to propose a reliable differential diagnosis of the tribe. Grubb (2000) grouped all Old World deer with small or missing upper canines and large complicated antlers into the single tribe Cervini Goldfuss, 1820. Possibly, the tribe Cervini Goldfuss, 1820 could be restricted to the phylogenetic branch of Cervus and related genera (or subgenera) Hyelaphus, 
Rusa, Panolia, and Przewalskium, since this cervid group shares similar cranial and dental characteristics (the presence of small upper canines, the narrow triangular basioccipitale) and genetical analysis revealed their monophyly (Pitra et al., 2004). However, the craniodental morphology of Plio-Pleistocene Eurasian Cervinae is still imperfectly studied and data for the classification of the subfamily Cervinae at the tribal level are insufficient.

\subsection{Zoogeographic context and origin}

The area of distribution of Megaceroides algericus limited by Atlas Mountains from the South has a refugial character, as it was reported for many other African species of Mediterranean affinity (Brito et al., 2011). Joleaud (1916) assumed that Megaceroides algericus dispersed into Northern Africa through the Strait of Gibraltar. According to Thomas (1979), the most plausible migration path for African deer is the "LibyanEgyptian" way, i. e. via the south and south-east coast of Mediterranean sea. Fernandez et al. (2015) consider that the way of dispersal across the Strait of Gibraltar seems to be more probable than the hypothetical arrival from the Libyan-Egyptian or Sicilian-Tunisian routes, which requires more evidences. The remains of Megaloceros, the most probable forerunner of Megaceroides algericus, are not known southern Italy (Lister, 1994). The undeniable remains of Megaloceros giganteus are reported only from northern part of Iberian Peninsula (Lister, 1994). The presence of giant deer in the area of Madrid (Sesé and Soto, 2000, 2002: page 332, fig. 16) and in the fauna of Bolomor Cave near Valencia (Peris et al., 1997: page 26) based on poorly diagnostic material that needs a confirmation. Van der Made (2014) described a new species Megaloceros novocarthaginiesis from the end of Early Pleistocene of Cueva Victoria, Spain. The new species is very close to Praedama savini (Dawkins, 1887) and differs from the latter only by somewhat larger size and higher position of the basal tine, therefore I prefer to include this species, if its taxonomic status will be confirmed, in the genus Praedama. Among noteworthy characters, the absence of any trace of cingulum in upper molars should be mentioned (van der Made, 2014).

The closer phylogenetic relationships between Megaloceros, Megaceroides, and Dama are supported also by paleobiogeographic data. The Mediterranean basin is the area of evolutionary radiation of the genus Dama (up to 7 fossil and modern species, including present day Dama dama from Anatolia and Dama mesopotamica from Near East), which is known only from Western Eurasia (Croitor, 2014). Until now, the highest taxonomical diversity of the genus Megaloceros is described from Western Europe (Azzaroli, 1953; Vislobokova, 2012a, 2012b, 2013). Therefore, Megaceroides algericus from the zoogeographic point of view is a part of evolutionary radiation of the Megaloceros-Dama lineage that took place in Western Eurasia and Mediterranean area. The medium-sized cervid from the Middle Pleistocene of Near East described by di Stefano (1996) as Dama clactoniana mugarensis is of special interest for the present discussion. This cervid form is characterized by a flattened antler beam, a flattened basal tine terminated by a bifurcation and a well-developed cingulum in upper molars (di Stefano, 1996). The lower premolar series seems to be relatively long $(66 \%$, measured from the photo in di Stefano, 1996) and represents a primitive condition similar to Megaloceros giganteus from Bisnik (Poland). The relatively robust radius of di Stefano's deer (radius length is ca. 215-220 mm, mid-shaft breadth is ca. $29 \mathrm{~mm}$ : di Stefano, 1996: fig. 8 ) is another character that distinguishes this cervid from the equal-sized representatives of the genus Dama and reminds the morphological condition described by Pomel (1893) in Megaceroides. Taking in account such specific characters, as cingulum in upper molars, low positioned flattened and bifurcated first antler tine, and flattened antler beam, one can assume that the medium-sized cervid from the Near East is a primitive or dwarfed form of giant deer Megaloceros mugarensis (di Stefano, 1996) and may represent a transitional form between Megaloceros and Megaceroides. 
The medium-sized Megaloceros mugarensis (di Stefano, 1996) from the Middle Pleistocene of Near East is the most probable forerunner of Megaceroides algericus. The indirect support for this assumption is provided by Thomas (1979), who reports the earliest scanty and poorly preserved fossil cervid remains from the Middle Pleistocene of North Africa.

\section{Conclusions}

Megaceroides algericus from the Late Pleistocene - Early Holocene of Northern Africa is a highly specialized cervid that evolved in the most extreme for the family Cervidae geographical area and environmental conditions. The genus Megaloceros from the Middle - Late Pleistocene of the boreal latitudes of Eurasia is phylogenetically nearest to Megaceroides. The medium-sized Megaloceros mugarensis (di Stefano, 1996) from the Middle Pleistocene of the Near East is the most probable forerunner of Megaceroides algericus and the linking form between Megaloceros giganteus and Megaceroides algericus. The most probable way of dispersal of Megaceroides algericus to Africa is the south-east coast of Mediterranean sea, the so-called "Libyan-Egyptian" way.

The unusual cranial morphology of Megaceroides algericus is regarded here as a combination of specific ancestral morphological and physiological characteristics (first of all, cranial pachyostosis) and new apomorphic characters (relatively diminished dentition with reduced size of $P_{2}, P^{2}, M_{3}$, and $M^{3}$, weak zygomatic arches and anterior part of mandible, short and broad splanchnocranium with shifted orally cheek tooth rows) that represent an adaptation to the new ecological niche, which permitted to avoid a direct competition with ecologically highly competitive bovids: this is a niche of a periaquatic or semiaqualic herbivore that feed on soft water plants. This explains the generally weak dentition and other cranial structures that are involved in the forage processing. The unusually thick helmet-like cranial bones acquired the new function of passive defense against the predators that usually wait for their prey at watering place. Unlike Megaloceros, the pachyostosis in Megaceroides ontogenetically evolved earlier in juvenile individuals with deciduous cheek teeth and had several cycles of seasonal growth. Phylogenetically, Megaceroides belongs to the Megaloceros-Dama branch and stands more close to Megaloceros.

The taxonomy of the subfamily Cervinae is poorly developed at the tribal level. The tribe Megalocerotini Brookes, 1828 sensu lato (= Megacerini Viret, 1961 fide Vislobokova, 1990, 2009, 2012a, b; 2013) is a polyphyletic group that includes specific large-sized eco-evolutionary type of cervids, which evolved independently in several lineages, and some poorly known forms that have similar apomorphic antler characters. The tribe Megalocerotini Brookes, 1828 sensu stricto with only genera Megaloceros, Megaceroides, and Dama represent a real phylogenetic branch, however, it is difficult to give an adequate taxonomical definition for this restricted group containing extremely specialized forms representing various eco-evolutionary types, first of all because the similar cervid eco-evolutionary types can be found in other phylogenetic branches of the subfamily Cervinae Goldfuss, 1820 (Geist, 1998).

\section{Acknowledgements:}

This research was supported by CNRS (2003) and Aix-Marseille University (2006). I thank Dr. Jean-Philippe Brugal (Maison Méditerranéenne des Sciences de l'Homme, Aix-en-Provence) for the provided possibility to carry out this study. Many thanks to Prof. Pascal Tassy (National Museum of Natural History in Paris) for the provided access to the fossil material, Dr. Paola Jenkins (Natural History Museum of London) and Dr. Paolo Agnelli (Zoological Museum "La Specola”, University of Florence) for access to the osteological material stored in the collections under their care. I also thank Dr. Gertrud Rößner and Dr. Jan van der Made for their valuable comments and criticism that helped to improve the article. I am grateful to Dr. Philippe Fernandez (Maison 
Méditerranéenne des Sciences de l'Homme, Aix-en-Provence) for the provided missing references and suggestions on age of the fossiliferous sites considered in the paper.

\section{References}

Abbazzi, L., 2004. Remarks on validity of the generic name Praemegaceros Portis 1920, and an overview on Praemegaceros species in Italy. Rendiconti Lincei, schienze fisiche e naturali Accademia dei Lincei 15, 115-132.

Abbazzi, L., Masini, F., 1997. Megaceroides solilhacus and other deer from the middle Pleistocene site of Isernia La pineta (Molise, Italy). Bollettino della Societa Paleontologica Italiana 35 (2), 213-227.

Alberts, B., Bray, D., Lewis, J., Raff, M., Roberts, K., Watson, J., 1983. The molecular biology of the cell. New York, Garland Publishing, $97 \mathrm{p}$.

Ambrosetti, P., 1967. Cromerian Fauna of the Rome Area. Quaternaria 9, 267-283.

Arambourg, C., 1932. Note préliminaire sur un nouvelle grotte à ossements des environs d'Alger. Bulletin Societe Histoire Naturelle Afrique du Nord 23, 154-162.

Arambourg, C. 1935. La Grotte de la Carrière Anglade à Guyotville (d'Alger). Bulletin de la Société d'Histoire Naturelle de l'Afrique du Nord 26 (1), 15-22.

Arambourg, C., 1938. Mammifères fossiles du Maroc. Mèmoires Société Sciences Naturelles Maroc 46, 1-74.

Arambourg, C., 1939. La Faune Fossile de l'Ain Tit Mellil (Maroc). Bulletin de la Société de Préhistoire du Maroc 12, 97-101.

Azzaroli, A., 1953. The Deer of the Weybourn Crag and Forest Bed of Norfolk. Bulletin of the British Museum (Natural History), Geology 2 (1), 3-96.

Azzaroli, A. 1961. Il nanismo nei cervi insulari. Palaeontographia Italica 56 (n. ser. 26), 1-31.

Azzaroli, A., 1979. Critical Remarks on some Giant Deer (genus Megaceros Owen) from the Pleistocene of Europe. Palaeontographia Italica 41 (N. Ser.), 5-16.

Azzaroli, A., 1994. Forest Bed elks and giant deer revisited. Zoological Journal of the Linnean Society 112 (1-2), 119-133.

Azzaroli, A., Mazza, P., 1993 Large early Pleistocene deer from Pietrafitta lignite mine, Central Italy. Palaeontographia Italica 80, $1-24$.

Bärmann, E. V., Sanchez-Villagra, M. R. 2011. A Phylogenetic Study of Late Growth Events in a Mammalian Evolutionary Radiation - The Cranial Sutures of Terrestrial Artiodactyl Mammals. Journal of Mammalian Evolution 19 (1), 43-56.

Brito, J.C., Martínez-Freiría, F., Sierra, P., Sillero, N., Tarroso, P. 2011. Crocodiles in the Sahara desert: an update of distribution, habitats and population status for conservation planning in Mauritania. PloS one 6 (2), e14734.

Caloi, L., Malatesta, A., 1974. Il Cervo Pleistocenico di Sardegna. Memorie dell'Istituto Italiano di Paleontologia Umana 2, $162-247$.

Caloi, L., Palombo, M.-R. 1995. Functional aspects and ecological implications in Pleistocene endemic cervids of Sardinia, Sicily and Crete. Geobios 28 (2), 247-258.

Camps, G., 1992. Le cerf en Afrique du Nord. Préhistoire et Antropologie Méditerranéenes 1992: 127-133.

Croitor, R., 1997. The Plio-Pleistocene deer of the Republic of Moldova. Their biostratigraphic and paleogeographic significance. Author's abstract of PhD dissertation. 26 p. Institute of Zoology, Academy of Sciences of Moldova.

Croitor, R., 2004. Systematics and phylogeny of large-sized deer of the genus Praemegaceros Portis, 1920 (Cervidae, Mammalia). In: R.-D. Kahlke, L. Maul (Eds.): Late Neogene and Quarternary biodiversity and evolution: Regional developments and interregional correlations. $18^{\text {th }}$ International Senckenberg Conference - VI International Palaeontological Colloquium in Weimar, 89-90. 
Croitor, R., 2006. Taxonomy and systematics of large-sized deer of the genus Praemegaceros Portis, 1920 (Cervidae, Mammalia). In: Kahlke, R.-D., Maul, L. C., Mazza, P. P. A. (eds.): Late Neogene and Quaternary biodiversity and evolution: Regional developments and international correlations. Volume I. Courier Forschungsinstitut Senckenberg 256, 91-116.

Croitor, R., 2009. Systematical position and evolution of the genus Arvernoceros (Cervidae, Mammalia) from Plio-Pleistocene of Eurasia. Oltenia. Studii şi comunicări. Ştiinţele Naturii 25, 375-382.

Croitor, R., 2014. Deer from Late Miocene to Pleistocene of Western Palearctic: matching fossil record and molecular phylogeny data. Zitteliana, B 32, 115-153.

Croitor, R., Bonifay, M.-F., 2001. Étude préliminaire des cerfs du gisement Pleistocène inférieur de Ceyssaguet (Haut-Loire). Paleo 13, 129-144.

Croitor, R., Bonifay, M.-F., Bonifay, E., 2006. Origin and evolution of the late Pleistocene island deer Praemegaceros (Nesoleipoceros) cazioti (Depéret) from Corsica and Sardinia. Bulletin du Musée d'anthropologie préhistorique de Monaco 46, 35 68.

Croitor, R., Kostopoulos, D. S., 2004. On the systematic position of the large-sized deer from Apollonia, Early Pleistocene, Greece. Paläontologische Zeitschrift 78 (1), 137-159.

Croitor, R., Stefaniak, K., Pawłowska, K., Ridush, B., Wojtal, P., Stach, M., 2014. Giant deer Megaloceros giganteus Blumenbach, 1799 (Cervidae, Mammalia) from Palaeolithic of Eastern Europe. Quaternary International 326-327, 91-104.

Di Stefano, G., 1996. The mesopotamian fallow deer (Dama, Artiodactyla) in the Middle East Pleistocene. Neues Jahrbuch für Geologie und Paläontologie - Abhandlungen 199 (3), 295-322.

Di Stefano, G., Petronio, C., 2000-2002. Systematics and evolution of the Eurasian Plio-Pleistocene Tribe Cervini ( Artiodactyla, Mammalia). Geologica Romana 36, 311-334.

Fernandez, P., Bouzouggar, A., Collina-Girard, J., Coulon, M., 2015. The last occurrence of Megaceroides algericus Lydekker, 1890 (Mammalia, Cervidae) during the middle Holocene in the cave of Bizmoune (Morocco, Essaouria region). Quaternary International 374, 154-167.

Fernández Peris, J., Guillem Calatayud, P. M., Martínez Valle, R., 1997. Cova del Bolomor: els Primers Habitants de les Terres Valencianes. Museo de Prehistoria and Sercivio de Investigacion Prehistorica, Valencia, $61 \mathrm{p.}$

Flerov, K. K. 1952. Musk deer and deer. The Fauna of USSR 1(2), Mammals. Academy of Sciences of the USSR, Moscow-Leningrad, 256 p. (in Russian).

Fortelius, M., Solounias, N. 2000. Functional characterization of ungulate molars using abrasion attrition wear gradient. American Museum Novitates 3301, 1-36.

Geist, V., 1998. Deer of the World: Their Evolution, Behavior and Ecology. Stackpole Books, $421 \mathrm{p}$.

Gentry, A. W. 2010. Cervidae. In : Werdelin, L. and Sanders, W. J. (Eds.): Cenozoic mammals of Africa: 813-814, University of California Press.

Geraads, D., 1986. Les Ruminants du Pleistocène d'Oubeidiyeh (Israel). Mémoires et travaux du Centre de recherches français de Jerusalem 5, 145-173.

Ginsburg, L., Hilly, J., Taquet, P. 1968. Une faune würmienne dans un remplissage de fente du massif du Filfila (littoral nordconstantinois, Algérie). Compte Rendu sommaire des séances de la Société géologique de France, 5, 157-158.

Grubb, P., 2000. Valid and invalid nomenclature of living and fossil deer. Acta Theriologica 45 (3), 289-307.

Hadjiouis, J., 1990. Megaceroides algericus (Lydekker, 1890), du gisement des Phacochères (Alger, Algérie). Etude critique de la position systematique de Megaceroides. Quaternaire 3-4, 247-258.

Heintz, E., 1970. Les Cervidés Villafranchiens de Franse et d’Espagne. Mémoires du Muséum national d’histoire naturelle. Série C, Sciences de la Terre 22 (1), 1-303 + (2), 1-206. 
Hughes, S., Hayden, Th. J., Douady, C, J., Tougard C., Germonpré, M., Stuart, A., Lbova, L., Carden, R. F., Hänni, K., Say, L. 2006. Molecular phylogeny of the extinct giant deer, Megaloceros giganteus. Molecular Phylogenetics and Evolution 40, $285-291$.

Janis, C. M., 1982. Evolution of horns in ungulates: ecology and palaeoecology. Biological reviews 57(2), 261-318.

Janis, C. M., 1990. Correlation of cranial and dental variables with body size in ungulates and macropodoids, in: J. Damuth, B. J. MacFadden, (Eds.), Body size in Mammalian Paleobiology: Estimation and Biological Implications. Cambridge: pp. 255-299.

Janis, C. M., 1995. Correlations between craniodental morphology and feeding behavior in ungulates: reciprocal illumination between living ans fossil taxa. In: J. Thomason, (Ed.), Functional morphology in vertebrate paleontology. Cambridge: pp. 76-98.

Joleaud, L., 1914. Sur le Cervus (Megaceroides) algericus Lydekker, 1890. Comptes rendus des séances de la Société de biologie et de ses filiales 76, 737-739.

Joleaud, L. 1916. Cervus (Megaceroides) algericus Leydekker, 1890. Recueil des Notices et Mémoires de la Société Archéologique du Département de Constantine 49 (6e volume de la cinquème série), 1-67.

Kahlke, H.-D., 1958. On the evolution of pachyostosis in jaw-bones of Choukoutien giant-deer Megaceros pachyosteus (Young). Vetrebrata Palasiatica 2 (2-3), 117-130.

Kahlke, H.-D., 1965. Die Cerviden-Reste aus dem Tonen von Voigtstedt in Thüringen. Paläontologische Abhandlungen. Abteilung A, Band 2, Heft 2/3, 381-431.

Kahlke, H.-D. 1969. Die Cerviden-Reste aus den Kiesen von Süssenborn bei Weimar. In: H.-D. Kahlke (Ed.), Das Pleistozän von Süssenborn. Paläontologische Abhandlungen A III (3-4), 547-611.

Kaiser, T. M., Schulz, E. L. 2006. Tooth wear gradients in zebras as an environmental proxy-a pilot study. Mitteilungen aus dem Hamburgischen Zoologischen Museum und Institut 103, 187-210.

Korotkevich, E. L., 1971. A new deer form from Neogene deposits of Southern Ukraine. Vestnik zoologii 1, 59-63.

Köhler, M. 1993. Skeleton and Habitat of recent and fossil Ruminants. Münchner Geowissenschaftliche Abhandlungen (A) 25, 188.

Kuehn, R., Ludt, C.J., Shroeder, W., Rottmann, O., 2005. Molecular phylogeny of Megaloceros giganteus - the Giant Deer or just a Giant Red Deer? Zoological Science 22, 1031-1044.

Lister, A. M., 1987. Case 2606: Megaloceros Brookes, 1828 (Mammalia, Artiodactyla): proposed emendation of the original spelling. Bulletin of Zoological Nomenclature 44 (4), 255-256.Lister A. M., 1994. The evolution of the giant deer, Megaloceros giganteus (Blumenbach). Zoological Journal of the Linnean Society 112, 65-100.

Lister, A. M., Edwards, C. J., Nock, D. A. W., Bunce, M., van Pijlen, I. A., Bradley, D. G., Thomas, M. G. Barnes, I., 2005. The phylogenetic position of the 'giant deer' Megaloceros giganteus. Nature 438 (8), 850-853.

Lydekker, R., 1890. On a cervine jaw from Algeria. Proceedings of Zoological Society 1890, 602-604.

Made, van der J., Tong, H. W., 2008. Phylogeny of the giant deer with palmate brow tines Megaloceros from west and Sinomegaceros from east Eurasia. Quaternary International 179, 135-162.

Made, van der J. 2014. The latest Early Pleistocene giant deer Megaloceros novocarthaginiensis n. sp. and the fallow deer Dama cf. vallonnetensis from Cueva Victoria (Murcia, Spain). In: Geología y Paleontología de Cueva Victoria. Mastia 11, 269-323.

Medig, M., Hadjouis, D., Sahnouni, M., Derradji, A., Sala, R. 2005. Les grottes paléolithiques de Taza. Archéologia 425, 64-69.

Morales, J., Pickford, M., Soria, D., 1992. Pachyostosis in a Lower Miocene giraffoid from Spain, Lorancameryx pachyostoticus nov. gen. nov. sp. and its bearing on the evolution of bony appendages in artiodactyls. Geobios 26 (2), 207-230.

Palombo, M.-R. 2005. Food habits of "Praemegaceros" cazioti (Depéret, 1897) from Dragonara Cave (NW Sardinia, Italy) inferred from cranial morphology and dental wear. Proceedings of the International Symposium "Insular Vertebrate Evolution: the Palaeontological Approach". Monografies de la Societat d'Història Natural de les Balears 12, 233-244. 
Pfeiffer, T., 1999. Die Stellung von Dama (Cervidae, Mammalia) im System plesiometacarpaler Hirsche des Pleistozäns Phylogenetische Rekonstruktion - Metrische Analyse. Courier Forschungsinstitut Senckenberg 211, 1-218.

Pitra, C., Fickel, J., Meijaard, E., Groves, P. C., 2004. Evolution and phylogeny of old world deer. Molecular Phylogenetics and Evolution 33, 880-895.

Pomel, A., 1892. Sur deux Ruminants de l'époque néolithique en Algérie : Cervus pachygenys et Antilope maupasi. Compte Rendu de l'Académie des Sciences 115, 213-216.

Pomel, A., 1893. Caméliens et Cervidés. Carte géologique de l'Algerie. Paléontologie monografies, 35-46.Radulesco, C., Samson, P., 1967. Sur un nouveau cerf megacerin du pleistocene moyen de la depression de Brasov (Roumanie). Geologica Romana 6, 317344.

Portis, A. 1920. Elenco delle specie di Cervicorni fossili in Roma e attorno a Roma. Bollettino della Societa Geologica Italiana 39, 132-139.

Reynolds, S. H. 1929. The Giant Deer. British Pleistocene Mammalia, vol. III, part III. London: Palaeontographical Society, pp. 1-62. Sanchez-Villagra, M. R. 2010. Suture closure as a paradigm to study late growth in recent and fossil mammals: a case study with giant deer and dwarf deer skulls. Journal of Vertebrate Paleontology 30 (6), 1895-1898.

Sesé, C., Soto, E. 2000. Vertebrados del Pleistoceno de Madrid. In: J. Morales (ed.) : Patrimonio Paleontológico de la Comunidad de Madrid. Conserjería de Educación, Comunidad de Madrid, 216-243.

Sesé, C., Soto, E. 2002. Vertebrados del Pleistoceno del Jarama y Manzanares. In: J. Panera Gallego, Rubio Jara, S. (eds.): Bifaces y Elefantes. La investigación del Paleolítico Inferior en Madrid, Zona Arqueológica 1. Madrid: Museo Arqueológico Regional, 318337.

Shikama, T., Okafuji, G., 1958. Quaternary cave and fissure deposits and their fossils in Akiyosi District. Science Reports Yokohama National University, Ser.2, 7, 105-112.

Shikama, T., Tsugawa, Sh., 1962. Megacerid remains from Gunma Prefecture, Japan. Bulletin of the National Science Museum (Tokyo) 50, 1-13.

Thomas, H., 1979. La faune quaternaire d'Algerie. Archeologia 134, 61-71.

Tleuberdina, P. A., 1982. Late Neogene fauna of South-East of Kazakhstan. 117 p., Alma-Ata.

Vaufrey, R. 1955. Prehistoire de l'Afrique. 1, Le Maghreb. Paris: Masson, $460 \mathrm{p}$.

Viret, J., 1961. Artiodactyla. Traite de Paleontologie, t. 6, v. 1. Paris: Masson et Cie, pp. 887-1084.

Vislobokova, I. A., 1990. The fossil deer of Eurasia. Transactions of Paleontological Institute 240, 1-208.

Vislobokova, I. A., 2009. A new species of Megacerini (Cervidae, Artiodactyla) from the late miocene Taralyk-Cher, Tuva (Russia), and remarks on the relationships of the group. Geobios 42, 397-410.

Vislobokova, I. A., 2012a. Giant Deer: Origin, Evolution, Role in the Biosphere. Paleontological Journal 46 (7), 643-775.

Vislobokova, I. A., 2012b. The History of Giant Deer (Megacerini, Cervidae, Artiodactyla). Transactions of the Paleontological Institute 293, 1-102.

Vislobokova, I. A., 2013. Morphology, Taxonomy, and Phylogeny of Megacerines (Megacerini, Cervidae, Artiodactyla). Paleontological Journal 47 (8), 833-950.

Wislocki, G. B., 1954. Antlers in Female Deer, with a report of Three Cases in Odocoileus. Journal of Mammalogy 35 (4), $486-495$.

Young, C. C., 1932. On the Artiodactyla from the Sinantropus site at Choukoutien. Palaeontologica Sinica C 8(2), 1-159.

Zdansky, O., 1928. Die Säugetiere der Quartärfauna von Chou-K'ou-Tien. Palaeontologica Sinica C 5 (4), 3-146. 
Table 1. Fossil material of Megaceroides algericus (Lydekker, 1890) from National Museum of Natural History in Paris studied in the present work.

\begin{tabular}{|c|c|c|c|}
\hline $\begin{array}{l}\text { Collection number and additional } \\
\text { information }\end{array}$ & Specimen & Site & Original citation \\
\hline $\begin{array}{l}\text { No number; labeled as "Cervus } \\
\text { algericus, figuré: PI. IV, Fig. 4", no } \\
\text { bibliographic reference. Here is } \\
\text { indicated as GM/1. }\end{array}$ & $\begin{array}{l}\text { The right hemimandible with } \mathrm{P}_{4^{-}} \\
\mathrm{M}_{3}\end{array}$ & $\begin{array}{l}\text { Grotte de la } \\
\text { Madeleine }\end{array}$ & $\begin{array}{l}\text { Described in Croitor (2006: Fig. } \\
2 \text { A-B, p. 94) as Megaceroides } \\
\text { algericus (Lydekker) }\end{array}$ \\
\hline No number; here is indicated as $\mathrm{GM} / 2$. & $\begin{array}{l}\text { The hemimandible with } \mathrm{M}_{2}-\mathrm{M}_{3}, \\
\text { showing a pathologic } \\
\text { malformation on processus } \\
\text { angularis }\end{array}$ & $\begin{array}{l}\text { Grotte de la } \\
\text { Madeleine }\end{array}$ & unpublished \\
\hline $\begin{array}{l}\text { No number, "Collection of } \\
\text { Arambourg". Here is indicated as the } \\
\text { "skull from Guyotville". }\end{array}$ & $\begin{array}{l}\text { The almost complete skull with } \\
\text { proximal parts of antlers }\end{array}$ & Guyotville & $\begin{array}{l}\text { Cervus (Megaceroides) } \\
\text { algericus Lydekker (Arambourg, } \\
\text { 1932: Fig. 3, p. 137) }\end{array}$ \\
\hline Nr. 336, "Collection of Arambourg" & $\begin{array}{l}\text { The left hemimendible with } M_{2} \\
\text { and } M_{3}\end{array}$ & Guyotville & unpublished \\
\hline Nr. 337, "Collection of Arambourg" & $\begin{array}{l}\text { The left hemimandible with } P_{4^{-}} \\
M_{3}\end{array}$ & Guyotville & unpublished \\
\hline MOC148, "Mission Arambourg" & $\begin{array}{l}\text { The damaged neurocranium with } \\
\text { frontal bones and a right basal } \\
\text { part of antler }\end{array}$ & Ain Tit Mellil & $\begin{array}{l}\text { Cervus (Megaceroides) } \\
\text { algericus Lydekker (Arambourg, } \\
\text { 1938: PI. II, Figs. 2, 2a) }\end{array}$ \\
\hline Fil-160 & The juvenile hemimandible & Filfila & unpublished \\
\hline Fil-166 & $\begin{array}{l}\text { The left complete hemimandible } \\
\text { with } \mathrm{P}_{2}-\mathrm{M}_{3}\end{array}$ & Filfila & $\begin{array}{l}\text { Megaceroides algericus } \\
\text { (Lydekker) (Thomas, 1979; } \\
\text { figured) }\end{array}$ \\
\hline Fil-167 & $\begin{array}{l}\text { The fragment of hemimandible } \\
\text { with } M_{2} \text { and } M_{3}\end{array}$ & Filfila & unpublished \\
\hline Fil-169 & The right maxilla with $\mathrm{M}^{2}$ and $\mathrm{M}^{3}$ & Filfila & unpublished \\
\hline No number; here is indicated as Fil/nn. & The fragment of mandible with $\mathrm{P}_{4}$ & Filfila & unpublished \\
\hline
\end{tabular}


Table 2. Cranial measurements of the modern and fossil deer involved in the present comparative study. CBL, condylo-basal length; $\mathrm{P}^{2}-\mathrm{M}^{3}$, length of upper cheek tooth row; $\mathrm{M}^{3}$-oc., distance between $\mathrm{M}^{3}$ and posterior edge of occipital condyle; $\mathrm{M}^{1}-\mathrm{M}^{3}$, length of upper molar series; $\mathrm{P}_{2}-\mathrm{P}_{4}$, length of upper premolar series; $\mathrm{P}^{2}$-pr., distance between $\mathrm{P}^{2}$ and prosthion; or-pr., distance between orbit and prosthion; Dor., horizontal diameter of orbit; or-oc., distance between orbit and posterior edge of occipital condyle.

\begin{tabular}{l|l|l|l|l|l|l|l|l|l|l}
\hline species & source/collection & $\mathrm{CBL}$ & $\mathrm{P}^{2} \mathrm{M}^{3}$ & $\mathrm{M}^{3} \mathrm{OC}$ & $\mathrm{M}^{1} \mathrm{M}^{3}$ & $\mathrm{P}^{2} \mathrm{P}^{4}$ & $\mathrm{P}^{2} \mathrm{pr}$. & or-pr. & Dor. & or-oc. \\
\hline $\begin{array}{l}\text { Praemegaceros } \\
\text { cazioti }\end{array}$ & $\begin{array}{l}\text { Caloi and } \\
\text { Malatesta (1974) }\end{array}$ & 300.0 & 101.0 & 132.7 & 62.0 & 45.0 & 73.5 & 149.0 & 44.0 & \\
\hline $\begin{array}{l}\text { Praemegaceros } \\
\text { obscurus }\end{array}$ & $\begin{array}{l}\text { IGF4024, Croitor } \\
(2014)\end{array}$ & 470.0 & 141.8 & 200.0 & 84.0 & 61.3 & 143.0 & 270.0 & & 140.0 \\
\hline Dama dama & $47.1 .1 .4(\mathrm{NHML})$ & 270.0 & 77.0 & 116.8 & 47.8 & 31.0 & 77.0 & 144.0 & 52.8 & 93.0 \\
\hline $\begin{array}{l}\text { Dama dama } \\
\text { Megaloceros } \\
\text { giganteus }\end{array}$ & $\mathrm{M} 28968(\mathrm{NHML})$ & 505.0 & 150.0 & 223.0 & 90.0 & 60.0 & 137.4 & 290.0 & 56.1 & 185.2 \\
\hline \begin{tabular}{l} 
Cervus elaphus \\
\hline
\end{tabular} & $1927-58(\mathrm{MNHN})$ & 353.0 & 109.8 & 131.4 & 68.7 & 45.2 & 111.8 & 207.0 & & \\
\hline
\end{tabular}

Table 3. Mandibular measurements of the modern and fossil deer involved in the present comparative study. C- $P_{2}$, length of diastema (distance between $C$ and $P_{2}$ ); $P_{2}-P_{4}$, length of lower premolar series; $M_{1}-M_{3}$, length of lower molar series; $M_{3}$-art., distance between $M_{3}$ and mandibular articulation; gn.- $M_{1}$, distance between gnation and $M_{1} ; M_{1}$-art., distance between $M_{1}$ and mandibular articulation; art.-gn., distance between mandibular articulation and gnation.

\begin{tabular}{l|l|l|l|l|l|l|l|l}
\hline species & source/collection & $\mathrm{C}-\mathrm{P}_{2}$ & $\mathrm{P}_{2} \mathrm{P}_{4}$ & $\mathrm{M}_{1} \mathrm{M}_{3}$ & $\mathrm{M}_{3}$-art. & gn.- $\mathrm{M}_{1}$ & $\mathrm{M}_{1}$-art. & art.-gn. \\
\hline Muntiacus muntjak & $\mathrm{c} .780$ (ZMS) & 40.0 & 24.5 & 38.0 & 34.4 & 67.3 & 64.3 & 135.6 \\
\hline Hydropotes inermis & $\mathrm{c} .1441$ (ZMS) & 42.0 & 20.2 & 32.3 & 32.8 & 70.3 & 57.1 & 126.4 \\
\hline Dama dama & c.12061 (ZMS) & 56.5 & 34.3 & 56.0 & 73.7 & 105.0 & 120.0 & 222.0 \\
\hline Praemegaceros cazioti & Cos19040, Croitor et al. (2006) & 50.4 & 37.6 & 62.0 & 80.0 & 115.0 & 126.2 & 235.0 \\
\hline
\end{tabular}


Table 4. Megaceroides algericus (Lydekker, 1890): cranial measurements.

\begin{tabular}{|c|c|c|}
\hline Measurements (mm) & Guyotville, =Ain-Benian (Algeria) & MOC-148, Ain Tit Mellil (Maroc) \\
\hline Condylo-basal length & $\sim 310$. & \\
\hline Distance between occiput and $\mathrm{P}^{2}$ & $\sim 255$ & \\
\hline Upper cheek teeth length, $\mathrm{P}^{2}-\mathrm{M}^{3}(\sin )$ & 91.4 & \\
\hline Upper premolar series length $(\sin )$ & 42.6 & \\
\hline Upper molar series length (sin) & 54.1 & \\
\hline Maximal breadth of skull (at orbits) & 193.3 & \\
\hline Bread of forehead begind orbits & 177.8 & \\
\hline Antero-posterior diameter of orbit $(\mathrm{dx})$ & 57.8 & \\
\hline Distance between occiput and orbit & 122.5 & \\
\hline Distance between orbit and prosthion & $\sim 150$. & \\
\hline Breadth of muzzle & 81.8 & \\
\hline Distance prosthion-nasion & $\sim 155$. & \\
\hline Distance nasion-bregma & 114.0 & 107.0 \\
\hline Distance prosthion-bregma & $\sim 290$. & \\
\hline Distance bregma-opistocranion & $\sim 85$ & 83.0 \\
\hline Breadth of braincase behind pedicles & 121.7 & 116.3 \\
\hline Height of occiput & & 86.0 \\
\hline Breadth of occiput & $\sim 162$ & 146.7 \\
\hline Breadth of occipital condyles & & 68.3 \\
\hline Diameter of pedicle $(\mathrm{DV} \times \mathrm{LM}$; $\mathrm{dx} / \mathrm{sin})$ & $46.3 \times 55.5 / 48.3 \times 50.0$ & $44.0 \times 49.3 /--$ \\
\hline Palatal breadth between PP 4 & 65.1 & \\
\hline Palatal breadth between $\mathrm{MM}^{3}$ & 68.4 & \\
\hline
\end{tabular}


Roman CROITOR - Geobios 49: 265-283 - 2016

Table 5. Megaceroides algericus (Lydekker, 1890): measurements of upper cheek teeth.

\begin{tabular}{|c|c|c|c|c|}
\hline \multirow{2}{*}{\multicolumn{2}{|c|}{ Tooth measurements (mm) }} & \multicolumn{2}{|c|}{ Guyotville (no number) } & \multirow{2}{*}{$\begin{array}{c}\text { Filfila (FIL169) } \\
d x\end{array}$} \\
\hline & & $\sin$ & $\mathrm{dx}$ & \\
\hline \multirow{2}{*}{$\mathrm{P}^{4}$} & length & 13.8 & 13.6 & \\
\hline & breadth & 19.1 & 19.0 & \\
\hline \multirow{2}{*}{$M^{1}$} & length & 17.8 & 18.7 & \\
\hline & breadth & 19.4 & 20.7 & \\
\hline \multirow{2}{*}{$M^{2}$} & length & 19.5 & 19.7 & 17.8 \\
\hline & breadth & 21.6 & 22.2 & 21.3 \\
\hline \multirow{2}{*}{$M^{3}$} & length & 18.9 & 18.7 & 16.1 \\
\hline & breadth & 20.8 & 21.0 & 18.2 \\
\hline
\end{tabular}


Table 6. Megaceroides algericus (Lydekker, 1890): measurements of lower mandibles; GM/1, unnumbered specimen from Grotte de la Madeleine with $\mathrm{P}_{4}-\mathrm{M}_{3} ; \mathrm{GM} / 2$, unnumbered specimen from Grotte de la Madeleine with malformation.

\begin{tabular}{|c|c|c|c|c|c|c|c|}
\hline \multirow{2}{*}{ Measurements } & FIL166 & $\mathrm{GM} / 1$ & $\mathrm{GM} / 2$ & GTV337 & GTV336 & FIL167 & FIL160 \\
\hline & $\sin$ & $d x$ & $\mathrm{dx}$ & $\sin$ & $\sin$ & & \\
\hline$L P_{2}-M_{3}$ & 95.2 & & & & & & \\
\hline $\mathrm{LP}_{2}-\mathrm{P}_{4}$ & 35.0 & & & & & & \\
\hline $\mathrm{L} \mathrm{M}_{1}-\mathrm{M}_{3}$ & 57.5 & 65.8 & & 61.6 & & & \\
\hline $\mathrm{L} \mathrm{M}_{2}-\mathrm{M}_{3}$ & 42.1 & 45.2 & 41.0 & 42.8 & 46.0 & 43.7 & \\
\hline L horizontal ramus & $215 .+$ & & & & & & \\
\hline L diastema & $45 .+$ & & & & & & \\
\hline $\mathrm{LP}_{2}$ - for. mentale & 20.3 & & & & & & \\
\hline $\mathrm{H}$ at $1 / 2$ diastema & 20.0 & & & & & & \\
\hline $\mathrm{H}$ under $\mathrm{P}_{2}$ & 18.7 & & & & & & \\
\hline $\mathrm{D}$ under $\mathrm{P}_{2}$ & 15.4 & & & & & & \\
\hline $\mathrm{H}$ under $\mathrm{M}_{1}$ & 21.5 & 19.0 & 20.3 & 19.8 & & & \\
\hline $\mathrm{D}$ under $\mathrm{M}_{1}$ & 21.8 & 22.8 & & 20.4 & & 21.2 & 19.0 \\
\hline $\mathrm{H}$ under $\mathrm{M}_{2} / \mathrm{M}_{3}$ & 30.8 & 34.6 & 33.4 & & 35.0 & 34.3 & 32.5 \\
\hline $\mathrm{D}$ under $\mathrm{M}_{2} / \mathrm{M}_{3}$ & 27.6 & 31.1 & 33.8 & 29.3 & 32.1 & 29.2 & 23.0 \\
\hline D maximal & 37.2 & 34.3 & 35.5 & 36.3 & 39.0 & 36.2 & \\
\hline $\mathrm{H}$ ascending ramus & 100.6 & & 96.0 & 108.4 & 109.2 & & \\
\hline L articulation - gnation & 230.0 & & & & & & \\
\hline $\mathrm{L}$ articulation $-\mathrm{M}_{3}$ & 88.3 & 75.2 & & & 92.7 & 84.5 & \\
\hline
\end{tabular}


Roman CROITOR - Geobios 49: 265-283 - 2016

Table 7. Megaceroides algericus (Lydekker, 1890): measurements of lower cheek teeth.

\begin{tabular}{|c|c|c|c|c|c|c|c|c|c|}
\hline \multicolumn{2}{|c|}{$\begin{array}{l}\text { Tooth } \\
\text { measurements }\end{array}$} & Fil-166 & Fil-167 & $\mathrm{Fil} / \mathrm{nn}$ & $\mathrm{GM} / 1$ & $\mathrm{GM} / 2$ & $\mathrm{Nr} .336$ & Nr.337 & $\begin{array}{l}\text { Pomel } \\
\text { (1892) }\end{array}$ \\
\hline \multirow[t]{2}{*}{$P_{3}$} & $L$ & 13.8 & & & & & & & \\
\hline & D & 9.3 & & & & & & & \\
\hline \multirow[t]{2}{*}{$\mathrm{P}_{4}$} & $\mathrm{~L}$ & 13.1 & & 13.6 & 15.5 & & & 13.7 & \\
\hline & $\mathrm{D}$ & 11.4 & & 10.2 & 11.7 & & & 10.4 & \\
\hline \multirow[t]{2}{*}{$\mathrm{M}_{1}$} & $L$ & 18.2 & & & 17.2 & & & 19.2 & \\
\hline & $\mathrm{D}$ & 14.3 & & & 13.9 & & & 14.0 & \\
\hline \multirow[t]{2}{*}{$\mathrm{M}_{2}$} & $L$ & 18.4 & 19.2 & & 19.8 & 18.0 & 20.2 & 19.0 & 20.0 \\
\hline & $\mathrm{D}$ & 13.8 & 14.0 & & 15.0 & 14.1 & 14.0 & 12.9 & 15.0 \\
\hline \multirow[t]{2}{*}{$M_{3}$} & $\mathrm{~L}$ & 23.9 & 24.1 & & 23.0 & 23.0 & 25.8 & 23.0 & 22.0 \\
\hline & $D$ & 11.7 & 11.7 & & 13.2 & 12.1 & 14.0 & 12.4 & 10.0 \\
\hline
\end{tabular}


Table 8. The comparative account of cranial characters and proportions (with respect to condylo-basal length, CBL) of Megaceroides algericus, Megaloceros giganteus and Dama dama.

\begin{tabular}{|c|c|c|c|}
\hline Characters & Megaceroides algericus & Megaloceros giganteus & Dama dama \\
\hline $\begin{array}{l}\text { 1. Length of face before } \\
\text { orbits }\end{array}$ & quite short ( $48.4 \%$ of $\mathrm{CBL}$ ) & relatively long ( $57.4 \%$ of CBL) & $\begin{array}{l}\text { moderately short }(53.3 \% \text { of } \\
\mathrm{CBL} \text { ) }\end{array}$ \\
\hline $\begin{array}{l}\text { 2. Relative breadth of } \\
\text { skull }\end{array}$ & $62.4 \%$ of $\mathrm{CBL}$ & $39.6-43.1 \%$ of $\mathrm{CBL}$ & $35.7-41.9 \%$ of CBL \\
\hline $\begin{array}{l}\text { 3. Angle between axes } \\
\text { of face and braincase }\end{array}$ & $\begin{array}{l}1350 \text { ( moderately flexed } \\
\text { neurocranium) }\end{array}$ & $\begin{array}{lll}1550 & \text { (little } & \text { flexed } \\
\text { neurocranium) } & \end{array}$ & 120 (flexed neurocranium) \\
\hline 4. Relative size of orbits & relatively large (18.6 \% of CBL) & relatively small (11.1 \% of CBL) & relatively large (19.6\% of CBL) \\
\hline $\begin{array}{l}\text { 5. Development of } \\
\text { pachyostosis }\end{array}$ & $\begin{array}{l}\text { Pachyostosis of cranial bones } \\
\text { and lower mandible strongly } \\
\text { developed }\end{array}$ & $\begin{array}{l}\text { Pachyostosis of cranial bones } \\
\text { and lower mandible strongly } \\
\text { developed }\end{array}$ & No pachyostosis \\
\hline $\begin{array}{l}\text { 6. Shape of parietal } \\
\text { bones }\end{array}$ & Flattened parietal bones & Flattened parietal bones & Convex parietal bones \\
\hline $\begin{array}{l}\text { 7. Shape of frontal } \\
\text { bones }\end{array}$ & Flattened frontal bones & Concave frontal bones & Convex frontal bones \\
\hline $\begin{array}{l}\text { 8. orientation of } \\
\text { pedicles }\end{array}$ & $\begin{array}{l}\text { Pedicles deflected caudally and } \\
\text { sideward }\end{array}$ & $\begin{array}{l}\text { Pedicles deflected caudally and } \\
\text { sideward }\end{array}$ & Vertically oriented pedicles \\
\hline $\begin{array}{l}\text { 9. Position of nasal } \\
\text { bones }\end{array}$ & $\begin{array}{l}\text { Posterior edge of nasal bones } \\
\text { extends behind the anterior } \\
\text { line of orbits }\end{array}$ & $\begin{array}{l}\text { Posterior edge of nasal bones } \\
\text { extends behind the anterior } \\
\text { line of orbits }\end{array}$ & $\begin{array}{l}\text { Posterior edge of nasal bones } \\
\text { extends behind the anterior } \\
\text { line of orbits }\end{array}$ \\
\hline 10. Position of orbits. & $\begin{array}{l}\text { Anterior edge of orbit situated } \\
\text { above } \mathrm{M}^{2}\end{array}$ & $\begin{array}{l}\text { Anterior edge of orbit situated } \\
\text { above } \mathrm{M}^{3}\end{array}$ & $\begin{array}{l}\text { Anterior edge of orbit situated } \\
\text { above } \mathrm{M}^{2}\end{array}$ \\
\hline $\begin{array}{l}\text { 11. Length of naso- } \\
\text { premaxillary suture }\end{array}$ & $\begin{array}{l}\text { Naso-premaxillary suture is } \\
\text { long }\end{array}$ & $\begin{array}{l}\text { Naso-premaxillary suture is } \\
\text { long }\end{array}$ & $\begin{array}{l}\text { Naso-premaxillary suture is } \\
\text { short }\end{array}$ \\
\hline $\begin{array}{l}\text { 12. Development of } \\
\text { preorbital fossae }\end{array}$ & reduced & reduced or well-developed & well-developed \\
\hline $\begin{array}{l}\text { 13. Development of } \\
\text { ethmoidal orifice }\end{array}$ & closed & reduced or completely closed & very large \\
\hline $\begin{array}{l}\text { 14. Size and shape of } \\
\text { bulla tympani }\end{array}$ & rather large and rounded & intermediate size & very large and rounded \\
\hline 15. Shape of mandible & $\begin{array}{l}\text { Ascending part of mandible is } \\
\text { sloped backward }\end{array}$ & $\begin{array}{l}\text { Ascending part of mandible is } \\
\text { set vertically }\end{array}$ & $\begin{array}{l}\text { Ascending part of mandible is } \\
\text { set vertically }\end{array}$ \\
\hline $\begin{array}{l}\text { 16. Development of } \\
\text { cingulum }\end{array}$ & A variing cingulum is present & A variing cingulum is present & No cingulum \\
\hline $\begin{array}{l}\text { 17. Angle between } \\
\text { lingual and labial sides } \\
\text { of } \mathrm{M}^{2}\end{array}$ & 370 & 450 & 370 \\
\hline
\end{tabular}


Roman CROITOR - Geobios 49: 265-283 - 2016

\begin{tabular}{l|l|l|l}
\hline $\begin{array}{l}\text { 18. Development of } \\
\text { upper canines }\end{array}$ & missing & missing & missing \\
\hline $\begin{array}{l}\text { 19. Position of upper } \\
\text { tooth row }\end{array}$ & displaced orally & in normal position & in normal position \\
\hline
\end{tabular}

